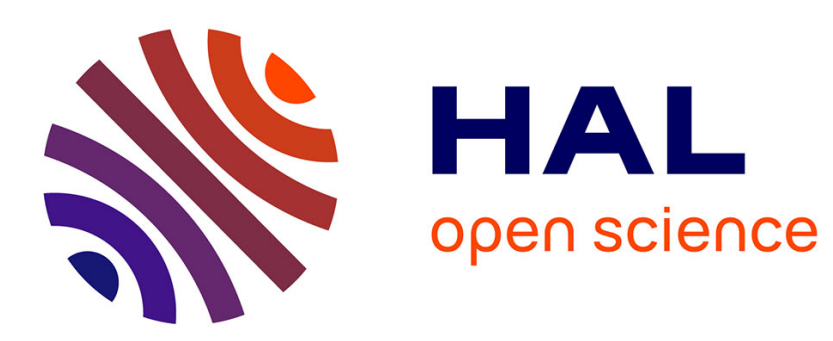

\title{
Cyclic variations of sulfate and boron concentrations and isotopes in deep groundwaters in the Aquitaine Basin, France
}

\author{
Laurent André, J.C Manceau, Pierre Bourbon, Arnaud Wuilleumier
}

\section{To cite this version:}

Laurent André, J.C Manceau, Pierre Bourbon, Arnaud Wuilleumier. Cyclic variations of sulfate and boron concentrations and isotopes in deep groundwaters in the Aquitaine Basin, France. Applied Geochemistry, 2020, 123, pp.104818. 10.1016/j.apgeochem.2020.104818 . insu-02990597

\section{HAL Id: insu-02990597 https://hal-insu.archives-ouvertes.fr/insu-02990597}

Submitted on 5 Nov 2020

HAL is a multi-disciplinary open access archive for the deposit and dissemination of scientific research documents, whether they are published or not. The documents may come from teaching and research institutions in France or abroad, or from public or private research centers.
L'archive ouverte pluridisciplinaire $\mathbf{H A L}$, est destinée au dépôt et à la diffusion de documents scientifiques de niveau recherche, publiés ou non, émanant des établissements d'enseignement et de recherche français ou étrangers, des laboratoires publics ou privés. 


\section{Journal Pre-proof}

Cyclic variations of sulfate and boron concentrations and isotopes in deep groundwaters in the Aquitaine Basin, France

By L. André, J.-C. Manceau, P. Bourbon, A. Wuilleumier

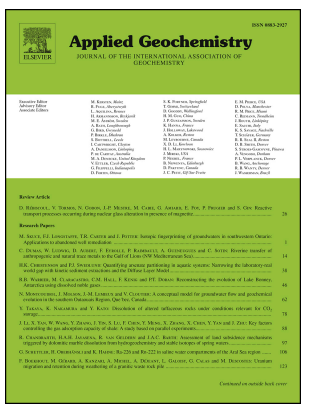

PII:

S0883-2927(20)30310-3

DOI: https://doi.org/10.1016/j.apgeochem.2020.104818

Reference: $\quad$ AG 104818

To appear in: $\quad$ Applied Geochemistry

Received Date: 2 August 2020

Revised Date: 21 October 2020

Accepted Date: 2 November 2020

Please cite this article as: André, B.L., Manceau, J.-C., Bourbon, P., Wuilleumier, A., Cyclic variations of sulfate and boron concentrations and isotopes in deep groundwaters in the Aquitaine Basin, France, Applied Geochemistry, https://doi.org/10.1016/j.apgeochem.2020.104818.

This is a PDF file of an article that has undergone enhancements after acceptance, such as the addition of a cover page and metadata, and formatting for readability, but it is not yet the definitive version of record. This version will undergo additional copyediting, typesetting and review before it is published in its final form, but we are providing this version to give early visibility of the article. Please note that, during the production process, errors may be discovered which could affect the content, and all legal disclaimers that apply to the journal pertain.

(c) 2020 Elsevier Ltd. All rights reserved. 


\section{Graphical abstract}

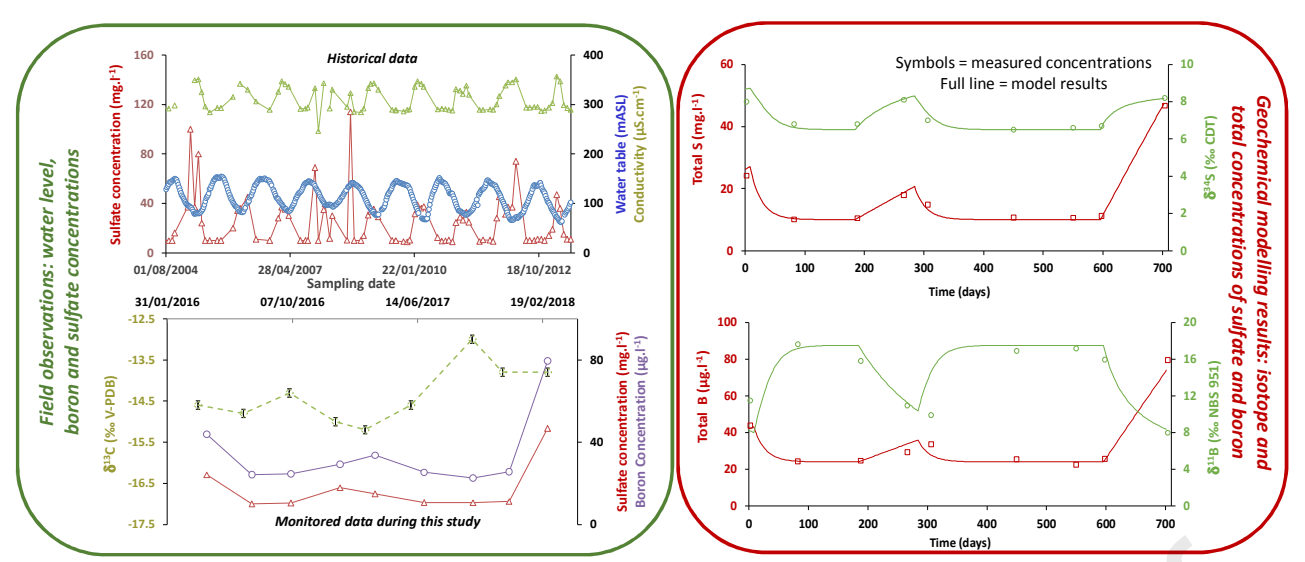


2 Cyclic variations of sulfate and boron concentrations and isotopes in deep groundwaters in the Aquitaine Basin, France

5

6 By L. André ${ }^{13^{*}}$, J.-C. Manceau ${ }^{1}$, P. Bourbon ${ }^{2}$, A. Wuilleumier ${ }^{2}$

7

81 BRGM Water, Environment, Process Development and Analysis Division, 3 Avenue Claude 9 Guillemin - 45060 Orléans Cedex - France

102 BRGM Aquitaine, Parc Technologique Europarc, 24, Avenue Léonard de Vinci, 33600 11 Pessac- France

123 Université d'Orléans, CNRS, BRGM, UMR 7327 Institut des Sciences de la Terre d'Orléans, 1345071 Orléans, France

14

15

16

17

18

19

20

21

22

23

24

25
First submission : July 2020

Revision : October 2020

${ }^{*}$ Corresponding author: l.andre@brgm.fr 


\section{Abstract}

Concentrations and isotope contents of major and trace elements are principal factors in determining the origin of the chemical composition of groundwater. This paper focuses specifically on the use of sulfur and boron isotopes to characterize the origin of cyclic variations in the deep Eocene aquifer in the Aquitaine sedimentary basin (southwest of France). It is part of a multi-layer system mainly composed of sands and sandstone deposits. Groundwater contained in this deep reservoir is known to present stable chemical compositions, allowing its use for various purposes like drinking water, geothermal energy, thermal activity and agricultural irrigation. However, among the dozens of wells exploiting this aquifer and despite the reservoir's substantial depth, variations in sulfate concentration have been identified in a limited area of the reservoir. These fluctuations are cyclic and they seem to be correlated with water level variations due to gas storage activities nearby in the same aquifer. Regular water samplings and analyses of major and trace elements and their isotopes have identified that bore concentration variations are correlated with sulfate variations. A geochemical modelling approach based on water mixes elucidates the causes of these variations in chemical composition, especially the boron and sulfate concentrations and their respective $\delta^{11} \mathrm{~B}$ and $\delta^{34} S_{\text {SO4 }}$ values. From these numerical results, we identify that different sources explain the variations of boron concentration, one part coming from the silicates alteration (present in sublayers of the exploited aquifer) and the other part coming from the evaporites alteration (present in the underlying molasse unit). These results also confirm the existence of mass and potentially water transfers between the different sub-layers of the reservoir and with the underlying molasse aquitard, implying new constraints for the future hydrogeologic modelling.

Keywords: deep aquifer; France; groundwater; sulfur stable isotopes; boron stable isotopes; mixing geochemical models. 


\section{1 - Introduction}

The Aquitaine basin is a wide sedimentary basin located in the southwest of France. It is constituted of aquitards and aquifers used for different purposes. Because of the various uses of the aquifers, the aquifer needs to be efficiently managed and the resources have to be investigated. To achieve this, public and private institutions initiated recent investigations on the Eocene aquifer through a scientific project named GAIA (Wuilleumier et al., 2018). This study embraces numerous areas of the earth sciences, including geology (Ortega et al., 2017), hydrogeology and hydrogeochemistry (Wuilleumier et al., 2018; Gal et al., 2018 a,b; André et al., 2018).

For the hydrogeochemistry research, the main goal is to investigate in detail the origin of water mineralization. The water chemistry in the Eocene aquifer (Aquitaine Basin - Southwest of France - Figure 1) has been investigated through different studies. Blavoux et al. (1993) were the first to investigate the isotope composition of the Eocene reservoir waters with characterization of ${ }^{2} \mathrm{H},{ }^{18} \mathrm{O}$, tritium, noble gases and carbon-14 activity. They defined that waters have a meteoric origin with a late Pleistocene origin. The authors concluded their article that the reservoir is a complex system and they did not exclude a recharge through the overlying molassic unit. They also supposed that additional investigations on sulphur components (including isotopes) could bring information on the origins for water mineralization. In agreement with these conclusions, isotopic analyses have helped to identify geochemical basins whose properties modify the chemical water composition (André, 2002; André et al., 2002; Douez, 2007). These studies showed that the $\delta^{34} S$ of gypsum sampled in the molasse unit was consistent with $\delta^{34} S$ values of dissolved sulfate in the reservoir waters. The study confirms the hypothesis of Blavoux et al. (1993) on the potential transfers between the molassic aquitard and the reservoir. Hydrogeochemical investigations continued with the CARISMEAU project (Négrel et al., 2007; 2009). During this study, the $\delta^{34} S$ of sulfate was also investigated in the Northern part of the reservoir (Entre-deux-mers area), coupled with other parameters like ${ }^{87} \mathrm{Sr} /{ }^{86} \mathrm{Sr}$ ratio (Brenot et al., 2015) or with fluoride measurements (Malcuit et al., 2014) to investigate the mineralization origin of waters. However, despite these investigations, some mechanisms are still unknown. Indeed, all the previous chemical investigations showed that the chemical composition of waters from this deep aquifer (about 500-1000 m depth) does not change usually with time. However, seasonal variations in sulfate concentrations occur in a specific area of the aquifer (Nogaro 2 well - Figure 2). About 200 samples collected at this well over more than 20 years show variations between 10 and about $100 \mathrm{mg} \mathrm{SO}_{4} \cdot \mathrm{I}^{-1}$ (sometimes higher). These varied sulfate concentrations are correlated with the water conductivity and anti-correlated with 
89

90

91

92

93

94

95

96

97

98

99

100

101

102

103

104

105

106

107

108

109

110

111

112

113

114

115

116

piezometric variations (reaching about $80 \mathrm{~m}$ per year), which are due to the impact of gas storage activities occurring within the same aquifer.

During this study, additional hydrogeochemical monitoring was implemented for two years to increase our understanding of the mechanisms underlying these sulfate fluctuations. We focused on how sulfate concentration changed over time but also investigated the other major elements, traces and isotopes in the waters of the Nogaro 2 well, which exploits the Eocene aquifer. The Nogaro 2 well (reference: BSS002EFSB - see Infoterre, 2020a) is used to supply drinking water to the city of Nogaro (Gers Department). It was drilled in 1982 and has been monitored regularly for chemical composition of groundwater. Two other wells located respectively 12 and $15 \mathrm{~km}$ from the Nogaro 2 well, were also monitored over the same period in order to compare the potential seasonal variations in the waters' chemical composition. Also used for drinking water supply, the Eauze well (reference: BSS002EGAG - see Infoterre, 2020b) and the Dému well (reference: BSS002EFZJ - see Infoterre, 2020c) pump within the same aquifer and are also influenced by the hydrogeologic conditions of this zone.

Chemical analyses focused on major and trace elements but also stable and radioactive isotopes. In coherence with former analyses, the new investigations confirm the sulfate variations (both total sulfur and ${ }^{34} \mathrm{~S}$ concentration). Isotopes of dissolved sulfate are widely used in large basins worldwide for identifying sulfur origins in water (De Caritat et al., 2005; Li et al., 2011; Einsiedl et al., 2015). ${ }^{34} \mathrm{~S}$ in sulfate is a geochemical tracer for obtaining information on the origin of sulfur and biological processes that may alter sulfate compositions in water (such as bio-sulfato-reduction). As part of this study, this isotope was tracked over time to better understand the origin of sulfate variations (André et al., 2002; Négrel et al., 2009). The new analyses on Nogaro 2 has also revealed remarkable boron variations (both total boron and ${ }^{11} \mathrm{~B}$ content) correlated with sulfur variations. ${ }^{11} \mathrm{~B}$ is a tracer used to define the origin of boron in solution, mainly the characterization of water/rock interactions in sedimentary basins (Négrel et al., 2012; Deiana et al., 2020), weathering processes in surface and subsurface systems (Lemarchand and Gaillardet, 2006; Ercolani et al., 2019), pollution sources and/or the anthropic inputs (Harkness et al., 2018) and salinization of coastal aquifers (Cary et al., 2015). The $\delta^{11} \mathrm{~B}$ value is also impacted by adsorption processes with a preferred adsorption of the light isotope $\left({ }^{10} \mathrm{~B}\right)$ and an enrichment of the solution in heavy isotope ${ }^{11} \mathrm{~B}$ (Palmer et al., 1987; Godfrey and Alvarez-Almado, 2020). At last, carbon-13 is a geochemical marker of water-rock interactions (including carbonates) and carbon-14 activity is used as an indicator of the apparent age of water. 
122 Our goal in this paper was to document the mechanisms controlling the variations in chemical 123 composition in the groundwater in this specific area and to identify potential causes of these

124 cyclic disturbances. After interpreting the chemical analyses, we carried out geochemical 125 modelling to characterize, from a mixing model, the different end-members (waters of different 126 horizons) that could be responsible for these concentration variations.

\section{2 - Geology, mineralogy and hydrogeological settings}

\section{1 - Geology}

129 The Aquitaine Basin is a large sedimentary basin limited in the east by the foothills of Montagne

130 Noire, in the south by the North Pyrenean Piedmont, in the west by the Atlantic Ocean and in 131 the north by the Poitou Plateau (Figure 1).

132 The area is characterized by a thick layer of detritic deposits (molasse) aging from late Eocene 133 to Miocene (Figure 2) and originating from the surrounding landforms (Massif Central, the 134 Montagne Noire and the Pyrenees mountains). This deposit starts at the beginning of the 135 Priabonian, when a drop in sea level led to a progression of late orogenic continental molassic 136 sediments (Orthiz, 2019). The development of the Campagne formation, mainly marly, 137 corresponds to a general regression and thus mark the continentalization of most of the Adour 138 basin, a sub-basin located in the southwest of Aquitaine Basin (Serrano, 2001). The lake and 139 river facies of these continental deposits have many evaporitic levels and numerous gypsum 140 indices were found in the Campagne formation (Priabonien). 


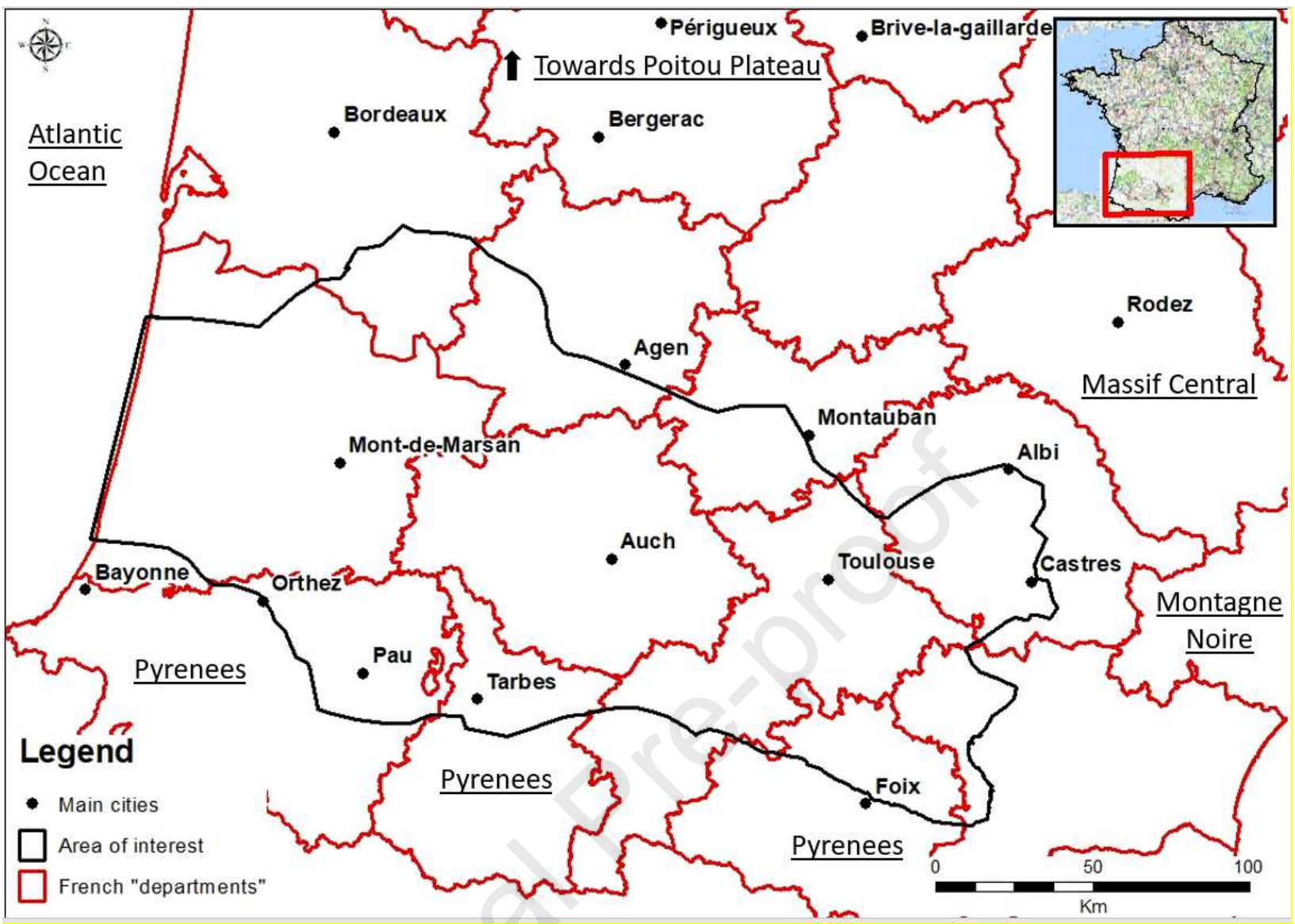

Figure 1 - Location map. The area of interest corresponds to the region investigated in the GAIA Project.

This formation overlies (Douez, 2007) the so-called Infra-Molassic Sands (SIM) of the early to mid-Eocene (Figure 2), which is mostly consisting of the Lussagnet sands of the Cuisian to Lutetian age, a prograding deltaic formation, and the underlying Nummulites sandstone of the Ypresien age, integrated into the Baliros sands formation. That sandy Eocene formation lies generally upon a layer of marl and clay deposits of the early Eocene and late Paleocene, which thickness usually ranges from 100 to some hundreds of meters (Beicip, 1984; Angrand, 2017), but, according to the location in the basin, it can lie directly upon the limestone and dolomitic limestone of the Paleocene (Douez, 2007). 


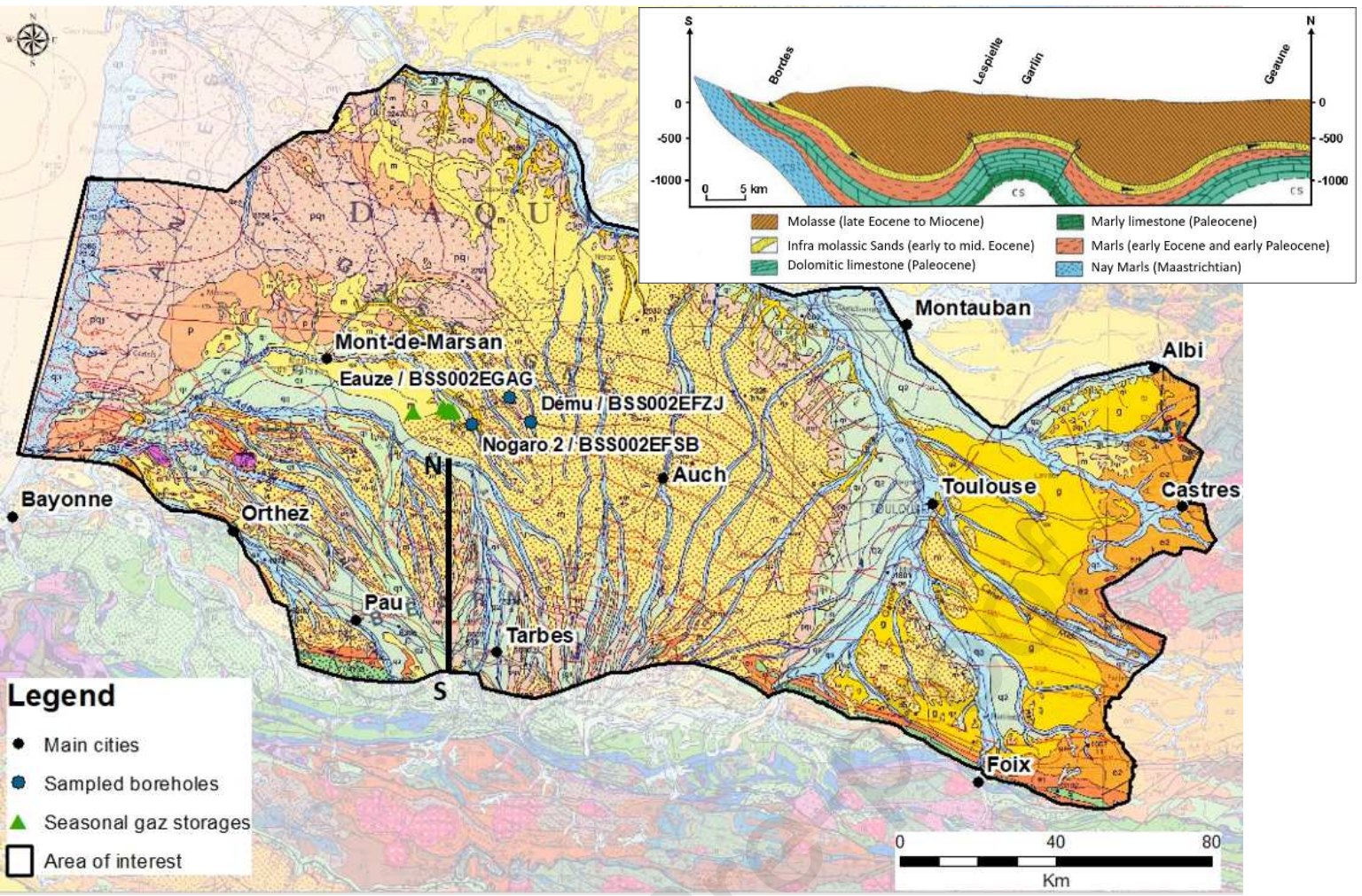

Figure 2 - Geological map (to 1 million) of the area and location of the three sampled wells: Nogaro 2, Eauze and Dému. Black line NS is a geological South-North schematic cross-section (adapted from Douez, 2007).

The depth of the top of the Eocene sand layer shows notable variations according to the location in the basin. The Nogaro 2 well corresponds to a low point with a depth of about $920 \mathrm{~m}$. The depth of the sand layer varies for many reasons. First, the thicknesses of the deposits may differ from one point to another in the sector depending on the amount of sediment stored during the progradation of the fan delta westward during the Middle Eocene, i.e. during the maximum peak of the Pyrenean compression, which corresponded to the maximum sediment discharge. In this type of context, the rate of movement of the delta position and the amount of detritus can change. Second, a massive but heterogeneous subsidence impacted the entire basin during the Pyrenean orogeny. During the Pyrenean compression responsible for this subsidence, the propagation of tectonic stresses also generated significant deformations in the South Aquitaine basin. At the origin of a "piercing" diapirism (particularly in the western part of the basin: Dax, Tercis, Bastenne-Gaujac, etc.) or of a "blind" diapirism (like in Audignon, Lacq,

171 Meillon), these long wavelength deformations affect part of the tertiary deposits, in particular by installing anticline structures (Bourrouilh et al., 1995; Serrano, 2001; AGSO and BRGM, 2018). 
The Eocene aquifer is a major aquifer in the Aquitaine sedimentary basin and it is used for uses such as drinking water, field irrigation, thermalism and spas, gas storage and as a thermal resource. This aquifer extends over $150 \mathrm{~km}$ from east to west and $200 \mathrm{~km}$ from south to north and constitutes a part of a multi-layer system. The Eocene sands aquifer is covered by several hundreds of meters of Tertiary molasse unit of low permeability. Therefore, the Eocene aquifer is confined over the studied area. Part of its outcrops are located in the South, close to the Pyrenees Mountains, and in the East, in the Montagne Noire region (Figure 1). At least, the mean annual air temperature at Mont-de-Marsan is $13.6^{\circ} \mathrm{C}$ for the $1981-2010$ period (MeteoFrance, 2020).

The average thickness of the Eocene aquifer varies according to the position in the basin from about $50 \mathrm{~m}$ to more than $200 \mathrm{~m}$. At the Nogaro 2 well, the thickness is close to $180 \mathrm{~m}$. The lithostratigraphic cuts obtained in the Nogaro 2 well clearly identify the presence of the Lussagnet sands aquifer (between 920 and $1001 \mathrm{~m}$ deep), which, from a hydrogeological point of view, forms the upper part of the Eocene sand aquifer in that area. The Lussagnet sands aquifer overlies the Baliros sands aquifer, which is the productive zone of the reservoir (between 1001 and $1092 \mathrm{~m}$ depth). This last part of the aquifer lies above a bioclastic calcareous layer (Horbaziou Formation) of low productivity (Infoterre, 2020a).

At Eauze, the Eocene aquifer is identified between 471 and $573 \mathrm{~m}$. The upper part is constituted of clay interlayers and the real productive part of the reservoir (i.e. the exploited portion) lies between 504 and $573 \mathrm{~m}$. It is made of sands and gravels of varying coarseness and overlies a grey calcareous horizon constituted of marls and sandstones with calcareous cement. At Dému, the well taps the Eocene aquifer between 740 and $780 \mathrm{~m}$. The reservoir is overlayed by $12 \mathrm{~m}$ of sands and gravels and Nummulites sandstone seems to lie beneath, but the well was not drilled below this depth and the nature of the lower horizons is unknown.

The porosity of the quartz sand deposit is estimated at 20-35\% (Housse and Maget, 1977; Douez et al., 2006). The average permeability (estimated from aquifer testing and modelling results) depends on the location and is generally accepted to range between $1.5 .10^{-4}$ and approximately $3.10^{-5} \mathrm{~m} . \mathrm{s}^{-1}$ (Labat, 1998; Seguin, 2003). The average interstitial velocity, using a gradient of 0.001 and an effective porosity of $20 \%$, is close to $5 \mathrm{~m} \cdot \mathrm{y}^{-1}$. Groundwater flow is mainly oriented from SE towards NW but outflow from the aquifer is not fully known. The estimated apparent age of the groundwater (using ${ }^{14} \mathrm{C}$ data and ${ }^{13} \mathrm{C}$ data for corrections with the Pearson and Hanshaw model, 1970) is close to 25-35 ky (André et al., 2018), which is consistent with the effective advection calculated above. 
207 The part of this aquifer that we studied is impacted hydraulically by gas storage at the 208 Lussagnet and Izaute sites. With a maximum authorized capacity of 6.5 billion $\mathrm{m}^{3}$, the two 209 storage facilities represent almost a quarter of France's underground storage capacity, 210 supplying natural gas to the southwest of France and also feeding other French and European 211 networks. The Lussagnet site has been implemented in 1957, prior to any piezometric 212 measurements, and the Izaute site in 1981, which influence of the static water level is recorded 213 since that date. Gas is stored on a relatively constant way throughout the year but monthly 214 consumption in the winter can be almost five times as high as in the summer months (TEREGA, 215 2020). Therefore, water pressure in the aquifer is submitted to high seasonal fluctuations (more 216 than 10 bars), inducing groundwater level variations around the storage zone. Fluctuations are 217 recorded all around the storage sites, like in Nogaro 2, Eauze and Dému, where static water 218 level variations can reach several tens of meters for these three wells (Figure 3).

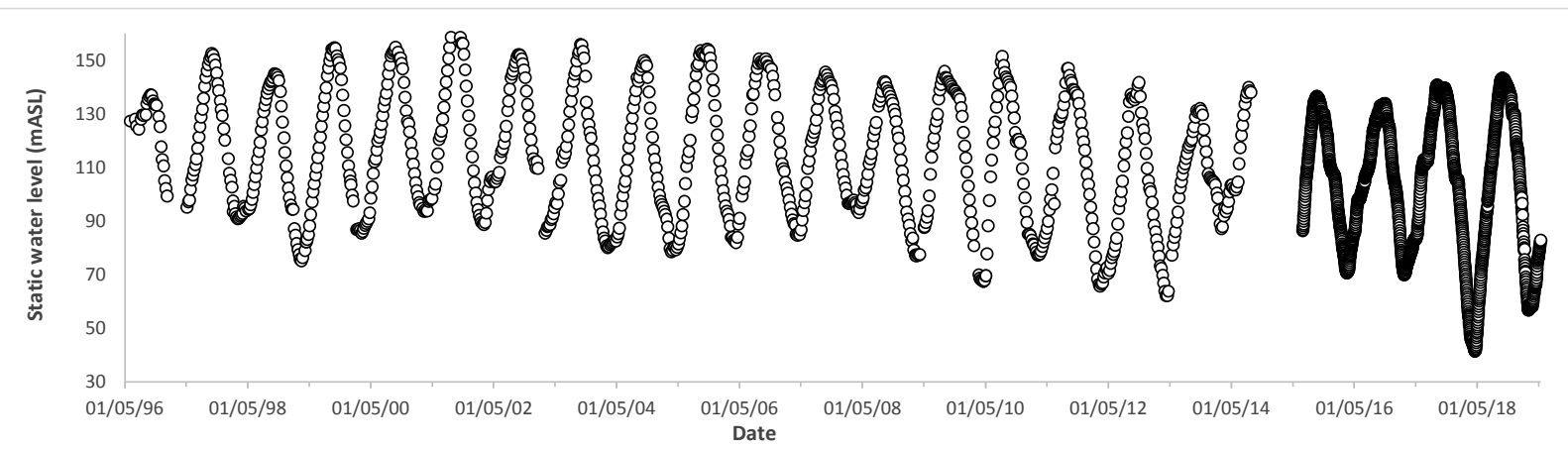



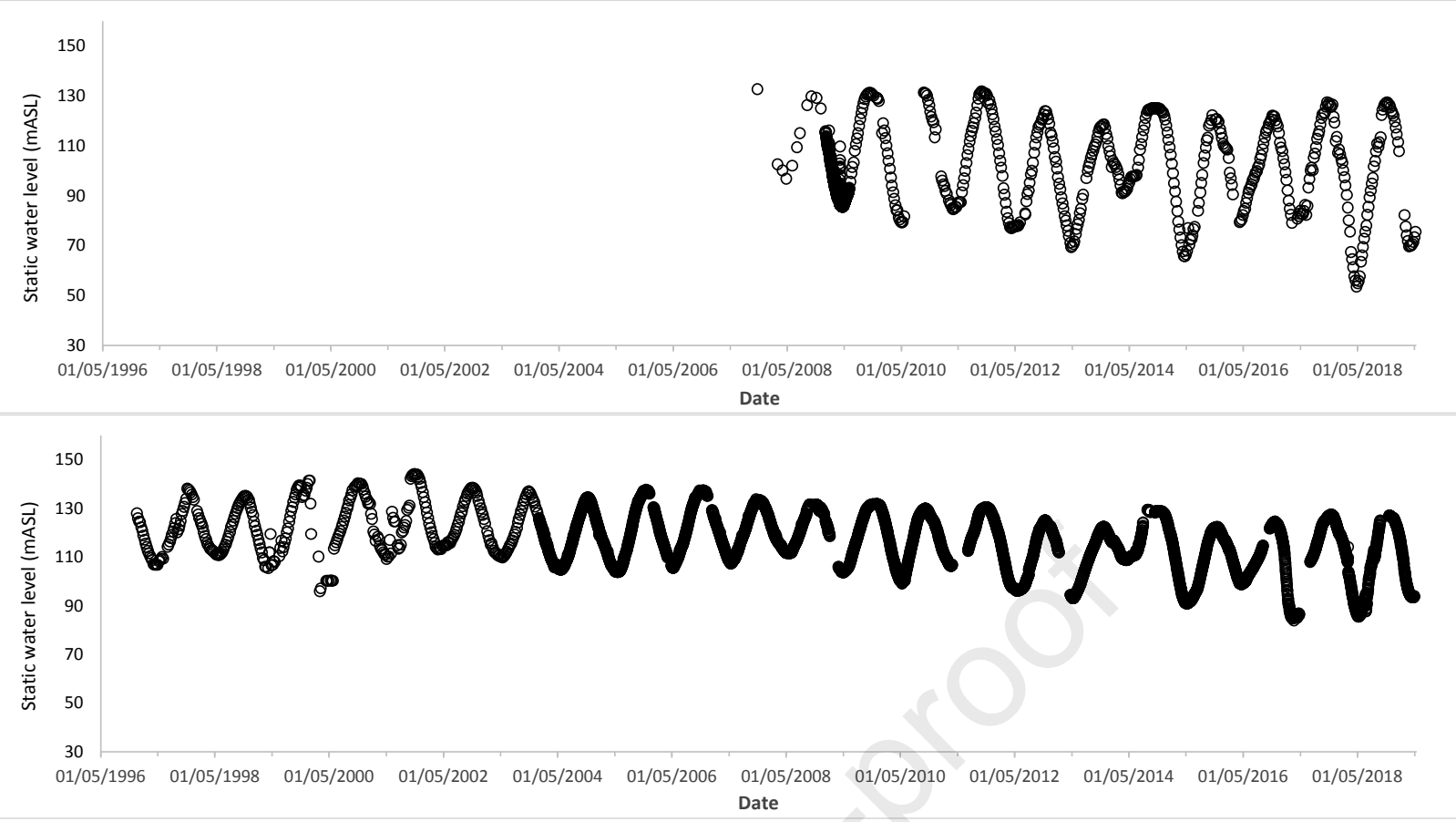

Figure 3 - Static water level recorded at three wells. Top: Nogaro 2; Middle: Eauze;

Bottom: Dému. The water level recording in Eauze starts in 2007, year of the wellbore drilling.

\section{3 - Mineralogy}

The mineralogy of the Eocene sands aquifer is relatively simple, containing mainly quartz augmented with calcite, and, in some places, dolomite and K-feldspars (André, 2002). In the Nogaro 2 well but also in other wells located in the zone of interest, pyrite indices were recognized sometimes in the Lussagnet sands and sometimes under the base of the Lussagnet sands aquifer, in the clay part of the Nummulites sandstones (Medium Eocene). More precise attempts to characterize this pyrite were made during this study in order to determine the $\delta^{34} S$ value of these sulfide minerals. Cuttings from a recently drilled well a few kilometres away from

242 Nogaro 2 were used to do this characterization. XRD analyses of these cuttings revealed the 243 presence of traces of pyrite (about 1\% in mass). Extractions were then carried out in 244 laboratories. However, it has proved impossible to isolate the pyrite properly to carry out isotopic analyses. The small amount, the grain size, and the pyrite being coated by quartz did not allow further analysis.

The mineralogy of the molasse sediments, although less well investigated, is richer, with quartz, feldspars, mica and several clay types (detrital limestone levels with sandy-clay deposits). At the lower part of the molasse deposits, crystallised gypsum has been observed in cuttings at many places. 


\section{3 - Water chemistry}

253 This study is based on two types of data: complete measurements of water chemical 254 composition recorded between 2016 and 2018 and historical data, corresponding to sulfate concentrations recorded for more than 20 years.

\section{1 - Sampling and analytical methods}

257 Nine sampling campaigns (April, July, October 2016, January, March, June, October, December 2582017 and March 2018) and chemical analyses were carried out over two years. The 259 investigated parameters measured on-site were physico-chemical data: temperature, 260 conductivity (standardized to $25^{\circ} \mathrm{C}$ ), redox potential (Eh), pH. Parameters are measured at the 261 wellhead, after purging the borehole. Water is collected only when physico-parameters are 262 stable.

263 The water samples were collected in polyethylene bottles as raw samples for $\delta^{18} \mathrm{O}-\delta^{2} \mathrm{H},{ }^{13} \mathrm{C}$ 264 analyses and ${ }^{14} \mathrm{C}$ activity measurements, and filtered through $0.45 \mu \mathrm{m}$ PVDF filters using a 265 Nalgene filter apparatus for chemical and boron, sulfate and strontium isotopes analyses. 266 Bottles dedicated to cation and strontium isotopes analysis were acidified with $15 \mathrm{~N}$ ultrapure $267 \mathrm{HNO}_{3}$ to $\mathrm{pH}<2$. A cadmium acetate solution was added to water samples dedicated to sulfate 268 isotopes analysis to precipitate sulfides, decrease $\mathrm{pH}$ and eliminate potential bacteria. Samples 269 were stored at $4{ }^{\circ} \mathrm{C}$ in the dark prior to analysis.

270 Major element concentrations are measured in BRGM's laboratory: $\mathrm{Ca}, \mathrm{Mg}, \mathrm{Na}, \mathrm{K}$ and silica 271 concentrations were measured by Inductively Coupled Plasma - Atomic Emission Spectroscopy 272 (NF EN ISO 11885 of November 2009) and $\mathrm{Cl}, \mathrm{SO}_{4}$ anions were analysed by ionic 273 chromatography (Standard NF EN ISO 10304 of 1 July 2009). The accuracy for all element 274 concentrations is $5 \%$, except $\mathrm{Na}$ and $\mathrm{K}$ with $10 \%$. Alkalimetry was measured by potentiometry 275 and $\mathrm{HCl}$ titration according to Standard NF EN ISO 9963-1 February 1996, with an accuracy of $27615 \%$.

277 Trace element concentrations ( $\mathrm{Al}, \mathrm{B}, \mathrm{Ba}, \mathrm{Li}, \mathrm{Mn}, \mathrm{Sr}, \mathrm{Br}$ ) were measured by inductively coupled 278 plasma mass spectrometry according to Standard NF EN ISO 17294-2 of April 2005, with 279 variable accuracy: Al 40\%, B 15\%, Ba 5\%, Li 10\%, Mn 10\%, Sr 10\% and Br 10\%. Total iron $280\left(\mathrm{Fe}_{\text {total }}\right)$ concentration was measured by Inductively Coupled Plasma - Atomic Emission 281 Spectroscopy (accuracy $10 \%$ ) and F by ionic chromatography with an accuracy of $5 \%$.

282 Accuracy and precision for major and trace elements was verified by repeated measurements of 283 standard materials during the course of this study: namely Merck etalon $\left(1 \mathrm{~g}^{\mathrm{I}^{-1}}\right)$ for $\mathrm{Ca}, \mathrm{Mg}, \mathrm{Na}$, 
284

285

286

287

288

289

290

291

292

293

294

295

296

297

298

299

300

301

302

303

304

305

306

307

308

309

310

311

312

313

314

315

316

317

$\mathrm{K}, \mathrm{Fe}, \mathrm{SiO}_{2}, \mathrm{Cl}, \mathrm{F}$ and a multi-element solution $\left(10 \mathrm{mg}^{-1}{ }^{-1}\right)$ from Inorganic Ventures for trace elements.

Stable isotopes concentration ratios $\left({ }^{2} \mathrm{H} /{ }^{1} \mathrm{H}\right.$ and $\left.{ }^{18} \mathrm{O} /{ }^{16} \mathrm{O}\right)$ of water molecules were analysed with a Finnigan ${ }^{\circledR}$ MAT 252 mass spectrometer connected to an automatic device, using the gas equilibration method ( $\mathrm{H}_{2}$ for hydrogen and $\mathrm{CO}_{2}$ for oxygen). The isotopic ratios are expressed in $\delta \% \circ$ vs V-SMOW ( Vienna Standard Mean Ocean Water). Precisions are $0.8 \% \circ$ for $\delta \mathrm{D}$ and 0.1 $\%$ for $\delta^{18} \mathrm{O}$.

For ${ }^{34} \mathrm{~S}_{\mathrm{SO} 4}$ and ${ }^{18} \mathrm{O}_{\mathrm{SO} 4}$ isotopic analysis, sulphides (precipitated as CdS after cadmium acetate adding) are first removed by filtration on $0.22 \mu \mathrm{m}$ membrane. Then, dissolved sulfates are precipitated as $\mathrm{BaSO}_{4}$ at $\mathrm{pH}<4$ by adding a $\mathrm{BaCl}_{2}$ solution. The precipitate of $\mathrm{BaSO}_{4}$ is then recovered on a $0.45 \mu \mathrm{m}$ filter and dried at $50^{\circ} \mathrm{C}$. For $\delta^{34} \mathrm{~S}_{\mathrm{SO} 4}, 250 \mu \mathrm{g}$ of $\mathrm{BaSO}_{4}$ are mixed with $\mathrm{V}_{2} \mathrm{O}_{5}$ in a tin capsule, and injected in a flash combustion elemental analyzer (Flash EA) where $\mathrm{BaSO}_{4}$ is reduced to $\mathrm{SO}_{2}$ at $1700^{\circ} \mathrm{C}$. The $\mathrm{SO}_{2}$ gas, purified by gas chromatography is then analyzed by CF-IRMS (Continuous Flow Isotope Ratio Mass Spectrometer) on a Thermo Scientific Delta V Plus spectrometer. For $\delta^{18} \mathrm{O}_{\mathrm{SO}}, 150 \mu \mathrm{g}$ de $\mathrm{BaSO}_{4}$ are placed in a silver capsule and injected into a graphite pyrolysis oven in a high temperature conversion elemental analyzer $(\mathrm{TC} / \mathrm{EA})$ at $1450^{\circ} \mathrm{C}$. The $\mathrm{CO}$ gas resulting from the reaction between oxygen and graphite is purified, and analyzed by CF-IRMS on a Thermo Finnigan Delta Plus XP spectrometer. Calibration ranges (from $-34.05 \%$ to $+21.12 \%$ for $\delta^{34} S_{S O 4}$, and from $-11.35 \%$ o to $+12.13 \%$ for $\delta^{18} \mathrm{O}_{\mathrm{SO} 4}$ ) are realised with three international standards (IAEA SO5, IAEA SO6, and NBS 127). The $S$ and $O$ isotope compositions are reported in the usual $\delta$-scale in $\%$ with reference to V-CDT (Vienna Canyon Diablo Troilite) and V-SMOW (Vienna Standard Mean Ocean Water). The sulfate-isotope compositions $\left(\delta^{34} \mathrm{~S}_{\mathrm{SO} 4}\right.$ and $\left.\delta^{18} \mathrm{O}_{\mathrm{SO} 4}\right)$ were measured with a precision of $\pm 0.3 \%$ vs. V-CDT for $\delta^{34} S_{\text {SO } 4}$ and $\pm 0.5 \% \circ$ vs. V-SMOW for $\delta^{18} \mathrm{O}_{\mathrm{SO} 4}$.

Boron isotopic compositions were determined on a Finnigan ${ }^{\circledR}$ MAT262 solid source mass spectrometer in a dynamic mode. For these samples, water volumes corresponding to a boron quantity of $10 \mu \mathrm{g}$ underwent a two-step chemical purification using Amberlite IRA-743 selective resin. The boron aliquot sample $(2 \mu \mathrm{g})$ was then loaded onto a Ta single filament with graphite, mannitol and $\mathrm{Cs}$, and the $\mathrm{B}$ isotopes were determined by measuring the $\mathrm{Cs}_{2} \mathrm{BO}_{2}{ }^{+}$ion. Total boron blank is less than $10 \mathrm{ng}$. Purified samples are always analysed twice. The values are given using the $\delta$-notation (expressed in \%o) relative to the NBS951 boric acid standard. The ${ }^{11} \mathrm{~B} /{ }^{10} \mathrm{~B}$ of replicate analysis of the NBS951 boric acid standard after oxygen correction was $4.05387 \pm 0.00120(2 \sigma, n=192)$ during this period (April-2016 to May-2018). The reproducibility of the $\delta^{11} \mathrm{~B}$ determination is then $\pm 0.3 \% \circ(2 \sigma)$. The internal uncertainty is often better than $0.2 \%$ 
$318\left(2 \sigma_{m}\right)$. Long-term accuracy and reproducibility of the overall procedure were verified by the 319 repeated measurements of the IAEA-B1 seawater standard (Gonfiantini et al. 2003) for which 320 the mean $\delta^{11} B$ value obtained is $39.20 \%$ o $\pm .30(2 \sigma, n=93)$ in accordance with the accepted 321 value for seawater.

322

323

324

325

326

327

328

329

330

331

332

333

334

335

336

337

338

339

340

341

342

343

344

345

346

347

348

349

350

351

Chemical purification of Sr was performed with an ion-exchange column (Sr-Spec) before mass analysis according to a method adapted from Pin and Bassin (1992), with total blank <0.5 ng for the entire chemical procedure. After chemical separation, around $150 \mathrm{ng}$ of $\mathrm{Sr}$ was loaded onto a tungsten filament with tantalum activator and analyzed with a Finnigan ${ }^{\circledR}$ MAT262 multicollector mass spectrometer. The ${ }^{87} \mathrm{Sr} /{ }^{86} \mathrm{Sr}$ ratios were normalized to a ${ }^{86} \mathrm{Sr} /{ }^{88} \mathrm{Sr}$ ratio of 0.1194 . An average internal precision of $\pm 10 \mathrm{ppm}\left(2 \sigma_{\mathrm{m}}\right)$ was obtained and reproducibility of the ${ }^{87} \mathrm{Sr} /{ }^{86} \mathrm{Sr}$ ratio measurements was tested through repeated analyses of the NBS987 standard for which we obtained, during the overall duration of this study, a mean value of $0.710246 \pm 0.000011$ $(2 \sigma, n=294)$. Sample ratios were normalized to the certified value of the NBS987 $(0.710240)$.

Carbon stable isotopes $\left({ }^{13} \mathrm{C} /{ }^{12} \mathrm{C}\right)$ and ${ }^{14} \mathrm{C}$ activity were analysed by Beta Analytic Inc. Water was first acidified with orthophosphoric acid under vacuum to get $\mathrm{CO}_{2}$. The gas is purified and a small aliquot fraction was used for the measurement of ${ }^{13} \mathrm{C} /{ }^{12} \mathrm{C}$ ratio by Isotopic Ratio Mass Spectrometry (IRMS). Measured ${ }^{13} \mathrm{C} /{ }^{12} \mathrm{C}$ ratios are calculated relative to the PDB-1 standard. $\mathrm{CO}_{2}$ was reduced by $\mathrm{H}_{2}$ into graphite over a cobalt catalyst. The ${ }^{14} \mathrm{C}$ measurements were performed by Accelerator Mass Spectrometry (AMS). The analytical result (in pMC) is obtained by measuring sample ${ }^{14} \mathrm{C} /{ }^{13} \mathrm{C}$ relative to the ${ }^{14} \mathrm{C} /{ }^{13} \mathrm{C}$ in Oxalic Acid II (NIST-4990C). The typical analytical uncertainty is about $0.1 \mathrm{pMC}(1 \sigma)$.

\section{2 - Historical data}

Nogaro 2 is a well used to provide drinking water. Because of this use, the water quality is regularly controlled. Since the sulfate concentration of waters exceeds sometimes drinking waters regulations (in France, the breakthrough value of sulfate concentration is $250 \mathrm{mg}^{\mathrm{I}^{-1}}$ ), a monthly monitoring is organized by the Regional Health Agency and monitoring is managed by the laboratory of the Gers department. However, this monitoring only focus on electrical conductivity and sulfate concentrations measurements without any information on other major and trace elements. All the chemical data acquired by both laboratories are registered on ADES website (ADES, 2020), a national database available for consultation. This hydrogeochemical monitoring revealed the variable sulfate concentration over time (Figure 4). From 2003-2015, between 6 and 12 measurements were made per year. While the chemical composition of the waters of the Eocene Sands aquifer varies only moderately over time, the waters show seasonal variation in sulfate concentrations. The lowest concentrations were of the order of 10 
$\mathrm{mg} . \mathrm{I}^{-1}$, while the strongest reached values greater than $100 \mathrm{mg} \cdot \mathrm{I}^{-1}$. Although sulfate was 353 monitored regularly, available water analyses were often incomplete and it was difficult to 354 correlate these variations in sulfate content with variations in other chemical elements.

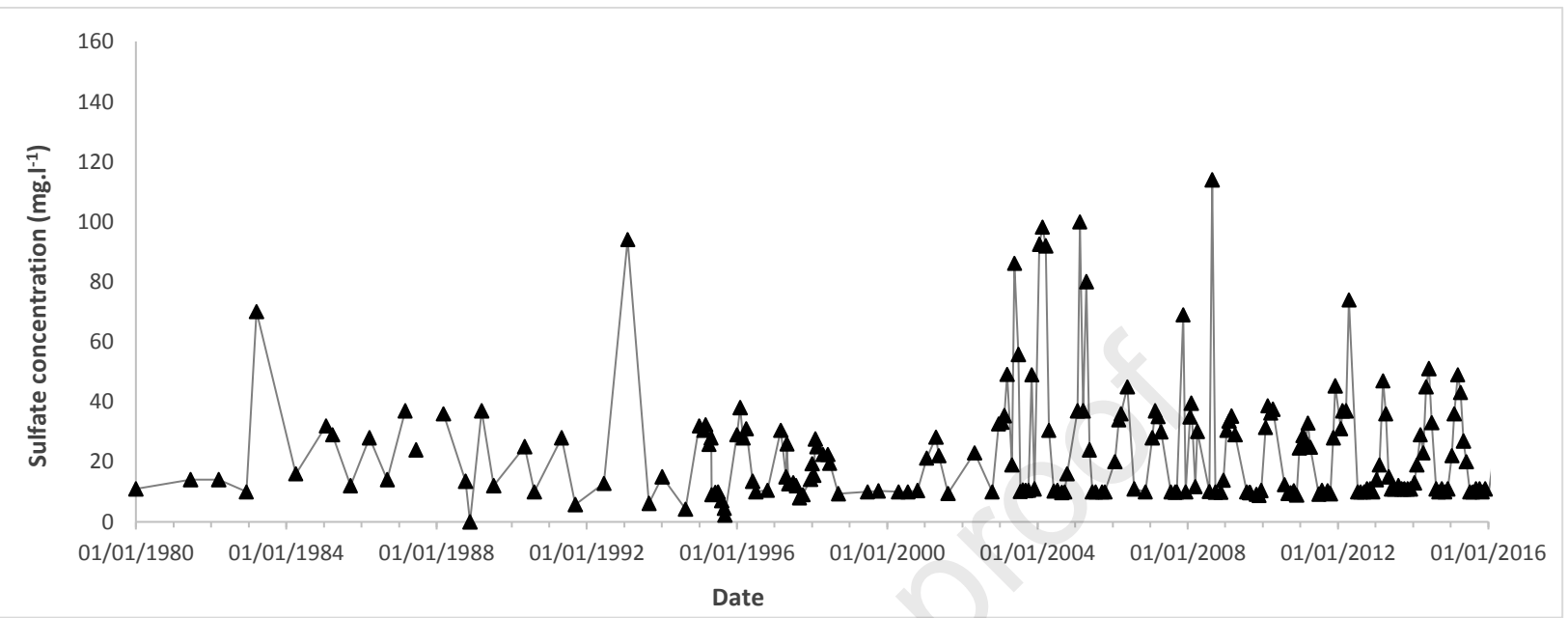

Figure 4 - Sulfate concentrations for waters in the Nogaro 2 well between 1980 and 2016

A visual comparison of piezometric levels and measured concentrations shows that high sulfate concentrations are found when piezometric levels are low (Figure 5). There is therefore an apparent anti-correlation between water level measurements and sulfate concentration measurements. We therefore assume the preeminent role of the pressure variations in the aquifer. We also observe that the shape of concentration cycles are different from the shape of hydraulic head variations: "concentration plateaus" of variable length separate the sulfate peaks whereas the hydraulic head looks like a sinusoidal curve. So the sulfate plateau reveals a

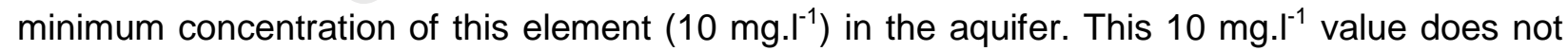
correspond to analytical limitations but to a real value of sulfate concentration in the reservoir. 


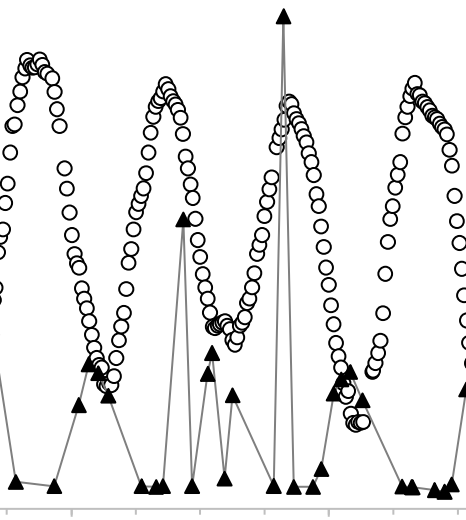

01/01/2009

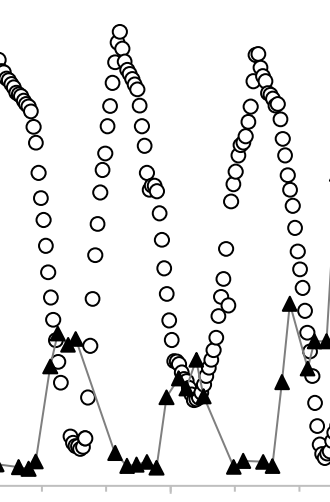

$02 / 01 / 2011$

Sampling date

Figure 5 - Water levels (open black circle) and sulfate concentrations (black triangles with grey line) for water from the Nogaro 2 well between 2003 and 2013

The Eauze well has been drilled quite recently (in 2007) and there has not been regular monitoring of sulfate concentration for this well (only 4 data points are available over the period 2007-2016). However, given the piezometric amplitudes over this period and the geographical proximity to the Nogaro 2 well, the question arises of how dissolved sulfate behaves in the water from this well.

The Dému well also has high piezometric amplitudes (about $30 \mathrm{~m}$ - Figure 3). However, based on the available data before this study, no correlation between piezometric level and concentrations could be found.

379 Consequently, the chemical cyclic behaviour observed at the Nogaro 2 well and potentially in other wells of the sector raises many questions on the origin of these fluctuations. However, given the available data and particularly the small number of complete chemical analyses, we decided to carry out quarterly monitoring of the chemical composition of the waters of the three wells. The aim was to be able to understand the reason for these variations, both in terms of chemistry and as an inferred consequence of the system's hydrodynamic behaviour.

\section{3 - Results}

\subsection{1 - Physico-chemical parameters}

Wellhead measured temperatures - reaching up to $53.9^{\circ} \mathrm{C}$ at Dému - show some variations for the three wells (see Appendix - Table A-1). These temperature differences are mainly due to 
390

391

392

393

394

395

396

397

398

399

400

401

402

403

404

405

406

407

408

409

410

411

412

413

414

415

416

417

418

419

420

421

422

not pumped continuously since the three of them are used for drinking water, with pumping fluctuations according to the hour of the day. The water temperatures of each well are consistent with the mean annual air temperature (MeteoFrance, 2020) and the mean geothermal gradient (ranging between 2.8 and $3.2^{\circ} \mathrm{C} / 100 \mathrm{~m}$ ) observed in the Aquitaine Basin (Housse and Maget, 1977).

Electric conductivity does not vary at Eauze whereas variations were observed of up to $10 \%$ at Dému and $30 \%$ at Nogaro 2 (See Appendix - Table A-1). These variations were due to changes in major element concentrations as described below.

Redox potential fluctuated greatly for the three wells, ranging from -300 to $+150 \mathrm{mV}$. The values were mostly negative, which is coherent with reduced waters pumped at such depths. However, interpreting such fluctuations is tricky since this parameter is always difficult to measure, especially for moderately hot waters containing oxidized and reduced species (e.g. $\mathrm{H}_{2} \mathrm{~S}$, sulfate, iron). The redox potential often corresponds to a global value impacted by different redox couples. We did not use this parameter for the interpretations.

Concerning $\mathrm{pH}$, the values ranged between 7.1 and 7.8 , which is coherent with waters whose $\mathrm{pH}$ is mainly controlled by calco-carbonic equilibrium with a relative low $\mathrm{CO}_{2}$ partial pressure, around $10^{-2}$ atm (André et al., 2005).

\subsection{2 - Major elements}

The major element concentrations are given in Appendix - Table A-2. Waters show a calcium bicarbonate facies, like most of the waters from the Eocene aquifer (André et al., 2005). They have a total dissolved solid concentration lower than $1000 \mathrm{mg.l}^{-1}$. Waters are generally at the equilibrium with quartz, calcite and a $\mathrm{CO}_{2}$ partial pressure close to $10^{-2} \mathrm{~atm}$, whereas they are undersaturated with respect to sulfate minerals (see calculated saturation indices in Appendix Table A-7). Since most of them have constant concentrations with time, Figure 6 focuses on sulfate alone. It shows how sulfate concentrations changed between January 2016 and March 2018 for the three investigated wells. For Nogaro 2, in addition to the nine sampling campaigns done by BRGM, the monthly sulfate concentration measurements organized by the Regional Health Agency are plotted on Figure 6. For Nogaro 2, three major sulfate concentration peaks were measured from January to April 2016 (with a maximum value of $34 \mathrm{mg}^{\mathrm{I}^{-1}}$ ), from March to

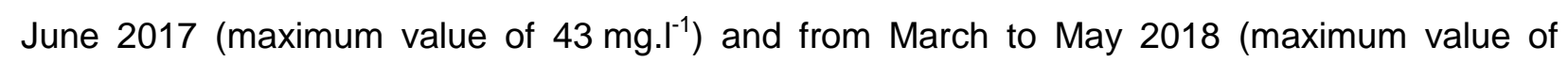
$\left.72 \mathrm{mg} . \mathrm{l}^{-1}\right)$. Sulfate concentrations for these peaks were 1.5 to 5 times the "reference sulfate concentration", estimated at $10 \mathrm{mg}^{\mathrm{I}^{-1}}$. Two very high sulfate concentrations were recorded during this period, the first one 3 January 2017 (with a value close to $300 \mathrm{mg} \mathrm{SO}_{4} . \mathrm{I}^{-1}$ ) and the 
other 5 September 2017 (with a value of about $82 \mathrm{mg} \mathrm{SO}_{4} \cdot \mathrm{I}^{-1}$ ). For the first one, the major increase of sulfate concentration is consistent with the water conductivity measurements, reflecting a substantial increase of water mineralization. However, as the major elements concentrations are not available for this sampling, it is impossible to confirm whether the value is consistent with the groundwater sulfate concentrations (analytical error, filtration issues in the samples, sulfate enriched particles, etc.) and with which other elements the sulfate would be correlated. It is also important to underline the brevity of this event since the sulfate concentration is about $18 \mathrm{mg} . \mathrm{l}^{-1}$ one week later.

432 The increased sulfate concentration in the Nogaro 2 waters seems to be correlated with 433 increased calcium and magnesium concentrations (See Appendix - Table A-2). The $(\mathrm{Ca}+\mathrm{Mg}) / \mathrm{Cl}$ 434 ratio clearly shows brief enrichment in $\mathrm{Ca}$ and $\mathrm{Mg}$ and the $(\mathrm{Ca}+\mathrm{Mg}) / \mathrm{SO}_{4}$ ratio decreases 435 drastically, underlying the enrichment in both calcium and sulfate in the solution. The Dému well waters are the most stable, with no observable seasonal variations in major anion and cation concentrations. Each calculated ratio confirms that these concentrations remain stable over time 438 (Figure 7). At the Eauze well, some variations in sulfate concentrations were observed in 439 October 2016 and December 2017. The increase was a much smaller proportion than at 440 Nogaro 2. The enrichment factor was about 1.2 compared to a base concentration of about 19$44120 \mathrm{mg.l}^{-1}$. The ratio $(\mathrm{Ca}+\mathrm{Mg}) / \mathrm{SO}_{4}$ was weakly impacted by this increased sulfate concentration 442 even though a slight decrease was observed in October 2016 and December 2017.

443 The piezometric level of the Nogaro 2 well (Figure 6) was anticorrelated with the increases in 444 sulfate concentrations in late winter-early spring 2016, 2017 and 2018: during these periods, the 445 sulfate concentration was at its highest when the piezometric level was at its lowest. These 446 observations hold if we exclude the two inexplicable peaks measured in January 2017 and 447 September 2017. For these two peaks, there are no anomalies on the piezometric data that 448 could explain these change in concentrations.

449 While at Nogaro 2, peaks in sulfate concentration were anti-correlated with the piezometric 450 level, for Eauze there is an almost positive correlation between sulfate concentration and 451 piezometric variations. Much more regular sampling over time (as in Nogaro 2) would help to 452 better define peak periods and thus better understand the links between these two variables 453 (phase shift, lag or simultaneous signal relative to the other). 


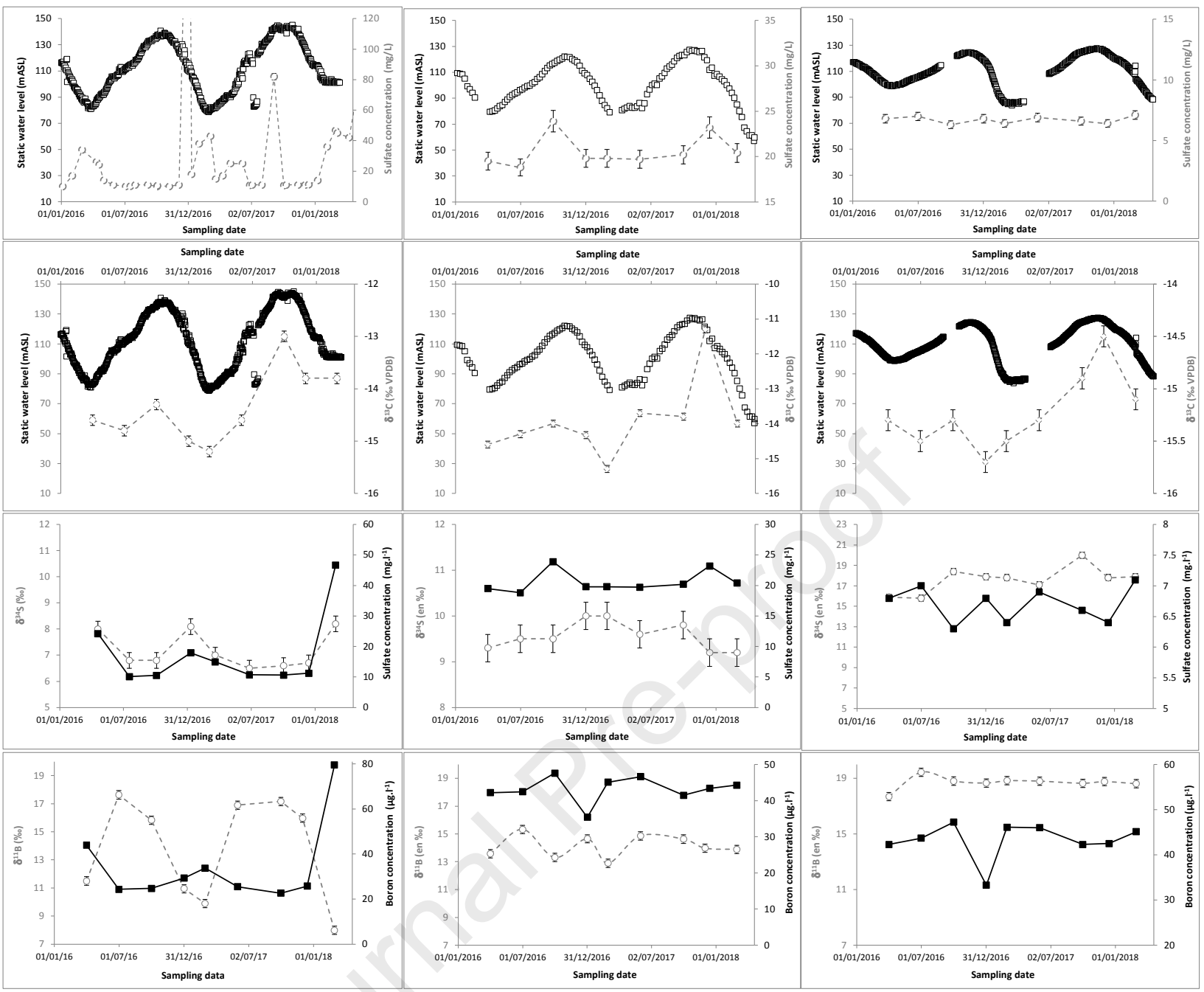

Figure 6 - Comparison between data measured during the project for wells: Nogaro 2 (left column), Eauze (centre column) and Dému (right column). First line of graphics: total sulfate concentration (dashed line) and static water level (black open symbols); second line of graphics: $\delta^{13} \mathrm{C}$ content (dashed line) and static water level (black symbols); third line of graphics: $\delta^{34} S$ in sulfates (dashed line) and total sulfate concentration (full line); fourth line of graphics: $\delta^{11} B$ (dashed line) and total dissolved boron concentration (full black line).

\subsection{3 - Trace elements}

Variations in $\mathrm{Al}, \mathrm{B}, \mathrm{Ba}, \mathrm{F}, \mathrm{Fe}, \mathrm{Li}, \mathrm{Mn}, \mathrm{Sr}$ and $\mathrm{Br}$ concentrations were measured in the waters of the three wells for all sampling campaigns (See Appendix - Table A-3).

Except the decrease in the strontium content in December 2017, for which we see no particular explanation (Perhaps a sampling or analytical problem?), strontium and barium concentrations were stable over time for the three wells (See Appendix - Table A-3). This stability in strontium is confirmed by isotope ${ }^{87} \mathrm{Sr}$ (see paragraph below). Barium concentration was low in waters 
and does not seem to be controlled by barite (see Appendix - Table A-7). The saturation indices of barite calculated with PHREEQC code (Parkhurst and Appelo, 2013) were close to 0.8/-0.9 for Demu waters and to $-0.20 /-0.30$ for Eauze waters. For Nogaro, because of the variation in sulfate concentration, the saturation indices range between 0.02 during sulfate peaks (like in March 2018) to -0.6 during low sulfate concentration phases (like in June 2017). Li concentrations do not vary with time, with values ranging between 8 and $15 \mu \mathrm{g} . \mathrm{I}^{-1}$. Al concentrations do not exceed $2 \mu \mathrm{g} . \mathrm{I}^{-1}$ and it seems controlled in some cases by equilibrium with montmorillonite or illite (See Appendix - Tables A-3 and A-7).

477 Finally, boron is the trace element that undergoes variations for all three wells. For the Nogaro 2 478 well, this variation is cyclical, with higher concentrations in April 2016, March 2017 and March 4792018 (Figure 6). The concentration reaches as much as $80 \mu \mathrm{g} . \mathrm{I}^{-1}$ and falls as low as close to $48020 \mu \mathrm{g} . \mathrm{I}^{-1}$. The variation of the concentration profile over time is similar to that of sulfate, with an 481 increase in April 2016, March 2017 and March 2018, and somewhat of a plateau for the other measurements (around $20 \mu \mathrm{g} \cdot \mathrm{I}^{-1}$ ). For Eauze and Demu, fluctuations were observed but in a less extent than in Nogaro since the concentration varies generally between 42 and $48 \mu \mathrm{g} . \mathrm{I}^{-1}$. There is no evidence of a cyclic evolution of the boron concentration. One value measured in January 2017 for both wells seems to fall outside of the range. It is lower by about $20 \%$ than all the other measurements at these two wells but there is no coincidence with abnormal values of boron isotopes (See paragraph on ${ }^{11} \mathrm{~B}$ isotope and Figure 6).

488

489

490

491

492

493

494

495

496

497

498

499 500

\subsection{4 - Isotopes}

Like for major and trace elements, we screened a wide range of stable and radioactive isotopes to identify potential tracers of the chemical mechanisms responsible for the observed variations. Isotopes of water $\left({ }^{2} \mathrm{H}\right.$ and $\left.\delta^{18} \mathrm{O}\right)$ and strontium isotopes $\left({ }^{87} \mathrm{Sr}\right)$ were measured during the first sampling campaigns (April 2016 to January 2017). They both had largely constant values and an absence of cyclic variations (see Appendix - Tables A-4 and A-5). Therefore, we focused more on interpreting the carbon, sulfate and boron isotopes. Isotopic compositions for stable isotopes of ${ }^{34} \mathrm{~S},{ }^{11} \mathrm{~B}$ and ${ }^{13} \mathrm{C}$ are reported in the usual $\delta$-scale, with $\delta_{\text {sample }}(\%)=\left\{\left(R_{\text {sample }} / R_{\text {reference }}\right)-1\right\} \times 1000$, where $R$ is the ratio of the numbers of heavy and light isotopes.

\section{- ${ }^{13} \mathrm{C}$ and ${ }^{14} \mathrm{C}$ in carbonates}

Carbon-13 and carbon-14 in carbonates were analysed during the study of the three wells (See Appendix - Table A-6). 
501 The waters of the Nogaro 2 show relatively stable carbon-14 activities, with small amplitude 502 variations around 2 pMC (see also Andre et al., 2019). The apparent age of the waters is about $503-30,000$ years BP according to Pearson and Hanshaw model (1970). $\delta^{13} \mathrm{C}$ has cyclic variations, 504 which seem to be correlated with the piezometric level over the period 2016-2018, with a high 505 value for this parameter at the maximum piezometric level in September 2017 (Figure 6).

506 We also observed the same variations and correlation between $\delta^{13} \mathrm{C}$ and the piezometric level 507 for the two other wells. $\delta^{13} \mathrm{C}$ variations reached about $3 \%$, as in Eauze, or only $1 \%$, as in 508 Nogaro 2 and Dému. These variations could indicate that potential chemical reactions and/or 509 water mixing processes could affect the $\delta^{13} \mathrm{C}$ value in solution.

\section{- ${ }^{34} \mathrm{~S}$ in sulfates}

511 For the Nogaro 2 well, variations in sulfur-34 follow the variations in total sulfur (Figure 6). 512 Indeed, when the sulfate concentration is close to $10 \mathrm{mg} \cdot \mathrm{I}^{-1}$, the $\delta^{34} \mathrm{~S}$ value is close to $+7.0 \%$. 513 Though total sulfate concentration and sulfur-34 increase, variations in sulfur-34 are relatively 514 small, as they do not exceed $2 \%$, even when the sulfate content is multiplied by 4 , as in March 5152018.

516 To sum up for the Nogaro 2 well, when the piezometric level is high, the sulfate content 517 decreases and carbon-13 content tends to increase (anti-correlation between sulfate and 518 carbon-13).

519 For the Eauze well, the relationship between the sulfate concentration and the $\delta^{34} S$ value is 520 much less pronounced than at Nogaro 2. The small seasonal variations in sulfate 521 concentrations (lower than $5 \mathrm{mg}^{\mathrm{I}^{-1}}$ ) correlated with piezometric fluctuations and the small 522 amplitudes recorded for $\delta^{34} S$ do not allow us to infer an accurate correlation.

523 For the Dému well, the variations in total sulfur concentration are very low (less than $1 \mathrm{mg}^{-1}{ }^{-1}$ ) 524 and confirmed by the absence of $\delta^{34} S$ variations. We note that the $\delta^{34} S$ was quite high (about $525+17 \%$ ), much higher than at the Eauze well (about $+9.5 \%$ ), which seems to indicate a different 526 origin for sulfur in solution.

528 The waters of the Nogaro 2 well show a cyclic and seasonal variation for $\delta^{11} \mathrm{~B}$ value. When the 529 boron content increased in water (April 2016, March 2017 and March 2018), the $\delta^{11} \mathrm{~B}$ 530 significantly decreased to reach the order of $+10 \%$ (Figure 6). When boron levels were lower 531 (on the order of $25 \mathrm{mg} \cdot \mathrm{I}^{-1}$ ), $\delta^{11} \mathrm{~B}$ increased to $+18 \%$ o. This finding seems to indicate a mix of the 532 initial water with $a^{11} \mathrm{~B}$-depleted solution. For Eauze well, the variations of $\delta^{11} \mathrm{~B}$ values are limited 
533 to $2 \%$. The relation between $\delta^{11} \mathrm{~B}$ and the total boron concentration is less remarkable than for

534 Nogaro 2 even if a cyclic variation can be supposed between mid 2016 and mid-2017. For 535 Demu well, $\delta^{11} \mathrm{~B}$ values are stable with time.

\section{$536 \quad 3.4$ - Geochemical modelling}

537 Analyses of major elements, trace elements and isotopes in the Nogaro 2 well waters confirm 538 cyclic variations in sulfate concentrations already observed in the chemical time series. These 539 sulfate concentration increases are correlated with increases in boron levels and anti-correlated 540 with static water level and ${ }^{13} \mathrm{C}$ content in the waters.

541 Based on sulfur-34 isotopic data, sulfate enrichment seems to come from a source with a $\delta^{34} S$ 542 greater than the base value in the reservoir (estimated here at $+6.5 \%$ CDT). For boron, the 543 increase in its total concentration coincides with a decrease of $\delta^{11} \mathrm{~B}$. In this case, the source of 544 boron responsible for the increase in concentration has a lower $\delta^{11} \mathrm{~B}$ value than the base value 545 in the reservoir (estimated at $+17.5 \%$ ).

546 To interpret these field results, simulations with the PHREEQC software (Parkhurst and Appelo, 547 2013) were carried out with the iso.dat database released with the code. Since boron-11 is not 548 in the database, the new species was implemented: parameters used to calculate the specific 549 volume of $\mathrm{H}_{3} \mathrm{BO}_{3}$ are from SUPCRT92 (Johnson et al., 1992), whereas the standard value 550 (4.04362\%) for ${ }^{11} \mathrm{~B} /{ }^{10} \mathrm{~B}$ is from Catanzaro et al. (1970). This software is particularly used in 551 geosciences because of its adaptability to geochemical problems of varying complexity. It offers, 552 among other things, the possibility of making geochemical calculations on isotopes, taking into 553 account the ratios of different species. The simulations consisted of reproducing variations in 554 sulfate and boron levels in the Nogaro 2 waters since this well presents the most significant 555 variations. The main objective was to be able to establish more precisely the values of $\delta^{34} S$ (in 556 sulfate) and $\delta^{11} \mathrm{~B}$ (for boron) that participate in these cyclical concentration variations. All 557 modelling was done in a batch system in which water mixtures (in the form of additions) were 558 simulated (Figure 7).

559 As shown in Figure 8, the initial water used for the simulations corresponded to the Nogaro 2 560 water analysed in April 2016, the beginning of quarterly samples, with an initial sulfate 561 concentration of around $24 \mathrm{mg.l}^{-1}$ (and $\delta^{34} \mathrm{~S}=+8.0 \%$ ) and a boron content of $44 \mu \mathrm{g} . \mathrm{I}^{-1}$ (and $562 \delta^{11} \mathrm{~B}=+11.5 \%$ ). The numerical simulations consisted of modelling two cycles, each comprising 563 two stages, namely a dilution phase (by mixing with a sulfate- and boron-depleted fluid) and a 564 concentration phase (by mixing with a fluid enriched with sulfate and boron). The durations of 
565 the dilution and concentration phases are consistent between simulations and on-site 566 measurements.

567 A first dilution phase lasting 180 days was then simulated. The dilutions were done by 568 successive additions of a Fluid 1 whose sulfate and boron contents were respectively $10 \mathrm{mg}^{-1}$ 569 and

$57024 \mu \mathrm{g} . \mathrm{I}^{-1}$ (Figure 7). If Fluid 1 was assumed to be initially in equilibrium with calcite and to have a $571 \mathrm{CO}_{2}$ partial pressure of $10^{-2} \mathrm{~atm}$, this equilibrium is not imposed during all the dilution phase (no 572 constraints on the calco-carbonic equilibrium). Initial $\mathrm{pH}$ of water is close to 7.35 and $\mathrm{Eh}=0 \mathrm{mV}$ 573 (consistent with measured values - see Appendix - Table A-1). The mixing consisted in adding 574 Fluid 1 by $5 \%$ in volume every day. The resulting sulfate and boron concentrations fell to 10 $575 \mathrm{mg} . \mathrm{I}^{-1}$ for sulfate (and $\delta^{34} \mathrm{~S}=+6.5 \%$ ) and $24 \mu \mathrm{g.I^{-1 }}$ for boron (and $\delta^{11} \mathrm{~B}=17.5 \%$ ). These 576 modelled variations were consistent with the measured groundwater concentrations, simulating 577 both the decrease and the plateau of sulfate concentration (Figure 8). 


Dilution 1 (180 days)

Figure 7 - Conceptual model of the geochemical modelling of the dilution and concentration stages impacting the Nogaro 2 waters.

581 Next, a first concentration phase was simulated over a period of 100 days (Figure 7). This phase was shorter since it only represented the increased sulfate concentration whereas the previous included both the decreasing sulfate concentration and the plateau. The added solution (called Fluid 2) had sulfate and boron concentrations of $1500 \mathrm{mg}^{-1}$ and $1620 \mu \mathrm{g} . \mathrm{I}^{-1}$, respectively. Fluid 2 was assumed to be in equilibrium with calcite to impose the carbon content corresponding to a $\mathrm{CO}_{2}$ partial pressure around $10^{-2.1} \mathrm{~atm}$. The isotope values were $+10.0 \%$ and $-3.2 \%$ for sulfur of sulfate and boron, respectively. These concentration and isotope values were calibrated to best represent the measured data. Among all the potential solutions, we took chose to consider the mixing fluid in equilibrium with gypsum, at the temperature of the reservoir. Since this water-mineral equilibrium fixes the sulfate concentration, it was then possible to determine both the amount of the added fluid and the $\delta^{34} S$ value of sulfate to match the measured data. The boron concentration was characterized according to the amount of fluid added and finally, the boron isotope value was defined. Fluid 2 was added in $0.0075 \%$ volume increments every day, which is a far lower percentage than during dilution 1 . That discrepancy 
between mixing proportions is addressed in section 4. The consequence of these successive additions was an increase in sulfate and boron concentrations and $\delta^{34} S$ and a decrease in $\delta^{11} \mathrm{~B}$ over time (Figure 8). The maximum peak values are respected.
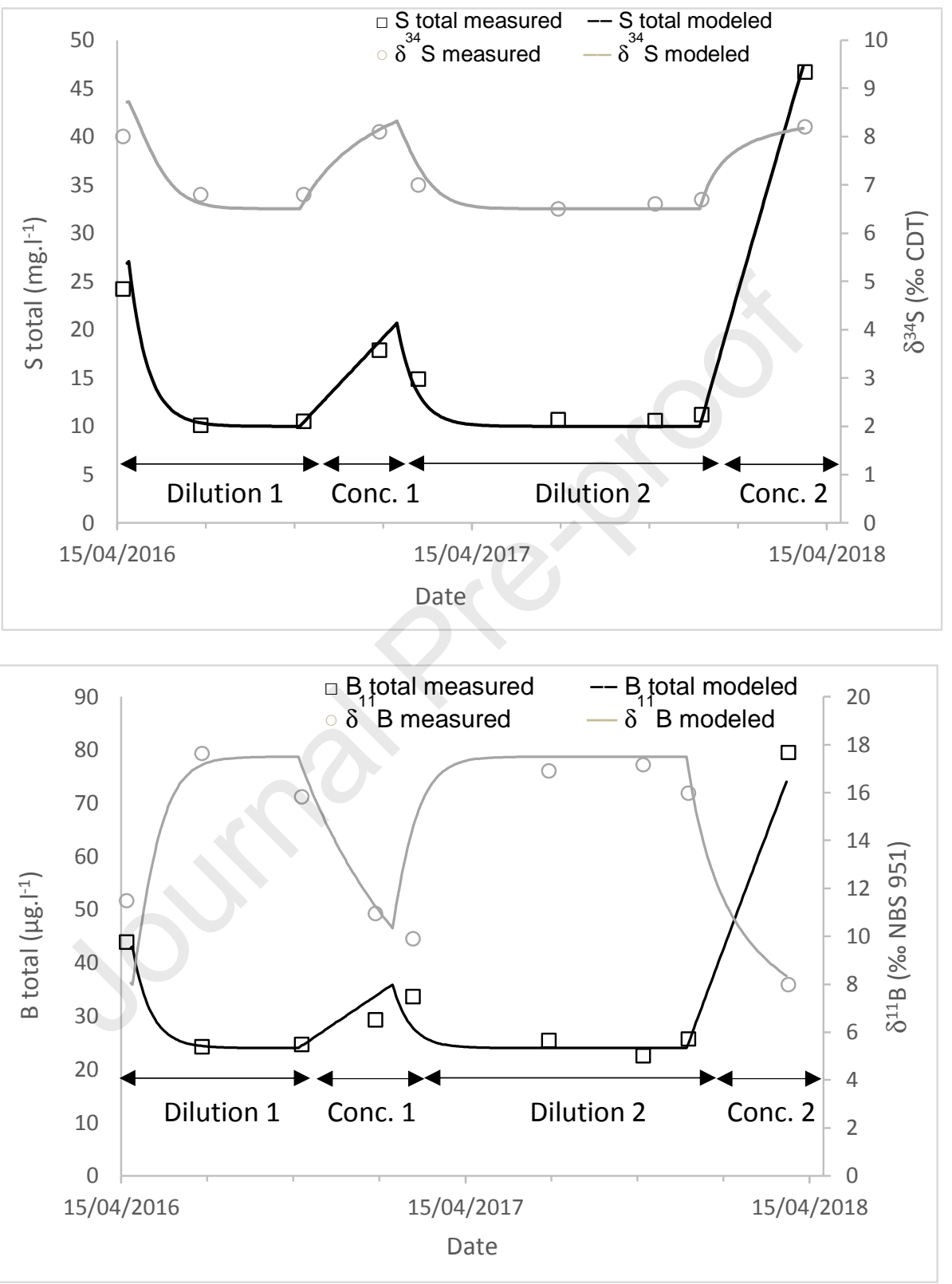

Figure 8 - Variations with time of (a) total sulfate concentration and $\delta^{84} S$; (b) total boron concentration and $\delta^{11} B$ in the Nogaro 2 water. Dilutions and concentration correspond to the stages defined in Figure 7. Symbols are data measured during this study.

603 The second cycle began with a dilution phase, significantly longer than the dilution during phase 6041 (300 days), so we reached the base values in the aquifer. Then a second concentration phase 605 over 100 days followed. During this phase, the maximum boron and sulfate concentrations were much higher than in the first concentration phase, whereas the final values of the isotopic 
values were similar to the initial values. This suggests that the mix is more complex than in the first case and another source of sulfate and boron is required. A new "recharge" solution (called Fluid 3) had to be defined, with sulfate concentrations on the order of $1000 \mathrm{mg}^{-1} \mathrm{I}^{-1}$ and a boron concentration of about $1620 \mu \mathrm{g} \cdot \mathrm{I}^{-1}$. Fluid 3 was assumed to be in equilibrium with calcite to impose the carbon content corresponding to a $\mathrm{CO}_{2}$ partial pressure around $10^{-2.1} \mathrm{~atm}$. Isotope values for boron and sulfur of sulfate were $+12 \%$ and $+6.5 \%$ CDT, respectively. As previously, these values were numerically determined to best represent the measured data. Each Fluid, 2 and 3 , was added in increments of $0.015 \%$ by volume every day. These additions increased the sulfate and boron contents in the mixture (to reach respectively $46 \mathrm{mg.l}^{-1}$ and $80 \mu \mathrm{g.l}^{-1}$ ), while respecting the values of measured isotopic ratios.

These geochemical simulations allowed us to estimate the concentrations and isotope compositions of waters that can mix with the Eocene aquifer groundwater to explain the cyclical variations, especially in sulfate and boron. These simulations relate to "classic" variations in sulfate concentration, but they do not represent exceptional variations, such as the sulfate concentration of $300 \mathrm{mg.l}^{-1}$ recorded in January 2017 as part of the Health monitoring of Nogaro 2 waters. According to these simulations, the "recharge" water used during the concentration phases had significantly higher sulfate and boron content than the waters of the aquifer.

\section{4 - Discussion}

626 This study confirms the cyclic variations of sulfur concentration observed during recent years in 627 the waters of Nogaro 2 well and also, but with a lower amplitude, at Eauze. There are no variations in Dému, which is farther from Nogaro 2. As discussed in André et al. (2002), sulfur in solution can have different origins. Some can come from precipitation (since water has meteoric origins), from gypsum dissolution, or from the oxidation of reduced sulfur minerals like pyrite.

631 Our study does not describe explicitly the potential chemical mechanism responsible for these 632 variations. But the numerical approach used in this study allows us to introduce some 633 hypotheses to explain these cyclic variations.

634 First, it seems that the Eocene groundwater (named Fluid 1) close to the Nogaro 2 well has a "base" sulfate concentration value of $10 \mathrm{mg.l}^{-1}$ and a $\delta^{34} \mathrm{~S}$ of $+6.5 \%$ CDT, which could reflect various origins for sulfur (mainly gypsum dissolution and a small part from pyrite oxidation according to André et al., 2002). The cyclic concentration increases could be due to mixing with a sulfate-enriched fluid. Many numerical solutions are possible since the chemical compositions of the added fluids and the proportion of the mix are unknown. We selected the option to 
641 reasons: first gypsum has been identified in the molasse horizon, at the top of the aquifer.

642 Molasse sediments are known to be a low-permeable media, fully saturated with water.

643 Because of the long contact time between water and the rock formations, we can assume that

644 the solution and minerals are in equilibrium. Secondly, since $\delta^{34} S$ varies by relatively low 645 amounts, the added fluid must have a $\delta^{34} S$ value close to the one in the reservoir. The 646 geochemical modelling shows that $\delta^{34} S$ of the mixed fluid is close to $+10 \%$ CDT, which seems 647 to be in coherence with an evaporitic origin of sulfate, like gypsum dissolution (André et al., 648 2002; Négrel et al., 2009 ; Malcuit, 2012). That is also consistent with values given in the 649 literature (Claypool et al., 1980) and it is not very far from the $+12.4 \%$ CDT measured on 650 gypsum crystals sampled in the molasse unit of the Aquitaine Basin (André et al., 2002). For 651 Fluid 3, the ${ }^{34} \mathrm{~S}$ selected had the same value than in the reservoir, which could indicate a higher 652 proportion of sulfur coming from sulfide minerals. $\delta^{18} \mathrm{O}_{\mathrm{sO} 4}$ for Nogaro 2 are close to +10.5 to $65314.6 \%$ with low variations with time, which is consistent with the mixing of sulfate having $654 \delta^{18} \mathrm{O}_{\mathrm{so} 4}$ value close to $14.9 \%$, like the one measured on the gypsum from molasse by André et 655 al. (2002).

656 For boron, the proposed $\delta^{11} \mathrm{~B}$ values were on the order of $-3.2 \%$ for Fluid 2 and $+12 \%$ of for Fluid 657 3. During this study, a new lab experiment was conducted to identify the potential origin of this 658 boron. We did not identify any boron-bearing mineral formally among the primary minerals in the 659 aquifer or in the molasse aquitard. Therefore, rock samples from cuttings and cores sampled at 660 the top of the aquifer (sampled in a neighbouring well drilled recently) were analysed (XRD 661 analysis, micro-probe and more) and laboratory tests were carried out to dissolve these 662 samples. The experiments consisted of dissolving $10 \mathrm{~g}$ of crushed material (cuttings) in $100 \mathrm{~mL}$ 663 of water and measuring, after one month, the concentrations of major and trace elements in the 664 aqueous solution. The experiments were carried out at a temperature of $38^{\circ} \mathrm{C}$ and atmospheric 665 pressure. We studied twelve samples from different geological horizons (molasse aquitard and 666 Lussagnet sands aquifer). After one month, analysis of the water phase showed quite large 667 disparities between the samples. Essentially, at a depth of $610 \mathrm{~m}$, i.e. in the heart of the 668 Lussagnet Sands aquifer, for which the depth ranges between $550 \mathrm{~m}$ and $650 \mathrm{~m}$, the $\delta^{11} \mathrm{~B}$ value 669 is similar to that used for the geochemical simulations (Figure 9). 


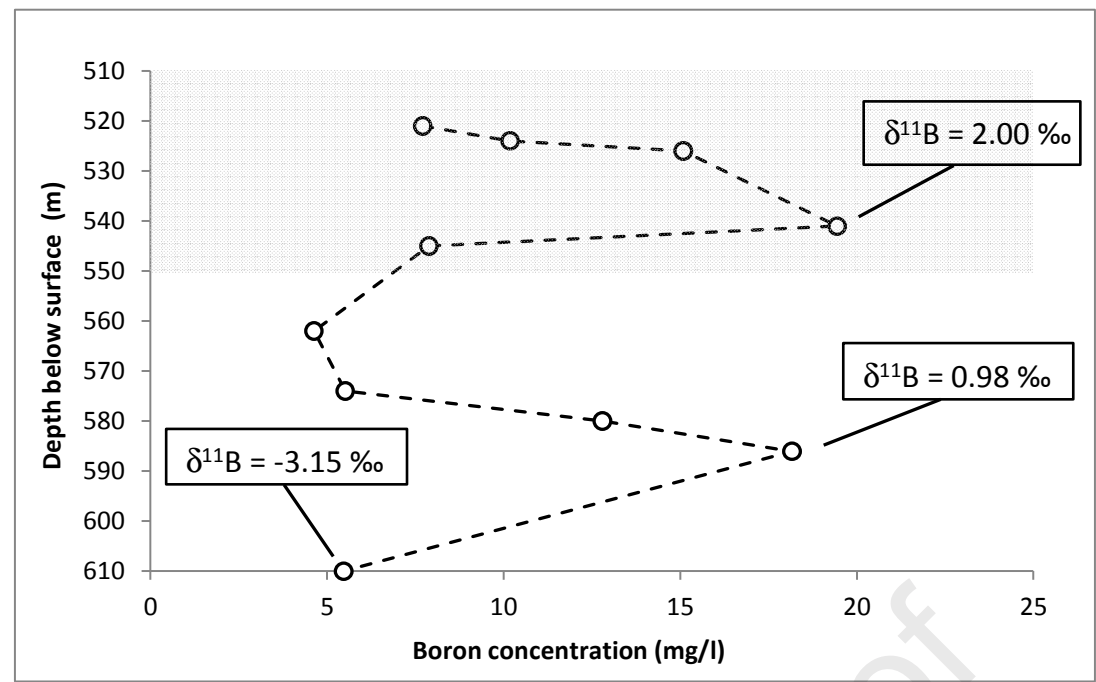

671 Figure 9 - Boron concentration and $\delta^{11} \mathrm{~B}$ values in the aqueous phase resulting from the lab 672 experiments on the dissolution of cuttings sampled at different depths from a well located near 673 the Nogaro 2 well. The top of the Lussagnet sands aquifer starts at a depth of $550 \mathrm{~m}$. The greyshaded zone indicates the molasse unit, which overlies the Lussagnet sand aquifer.

676 Because of the low $\delta^{11} \mathrm{~B}$ values identified in the Lussagnet sand aquifer (between -3.15 and $677+2.00 \%$ o), it could be inferred that boron may come from the alteration of silicates. Indeed, the 678 alteration of silicate minerals by waters gives low $\delta^{11} \mathrm{~B}$ values, ranging between -10 and $+10 \%$ 679 (Barth, 2000; Pennisi et al., 2000; Casanova et al., 2002; Négrel et al., 2002 ; Lemarchand and 680 Gaillardet, 2006; Millot et al., 2007; Clauer et al., 2018). As shown in Figure 10, this value is 681 also consistent with the end-member of silicates identified by Negrel et al. (2009). The boron 682 content of Fluid 2 could be explained by the alteration of the silicate sands of Lussagnet and 683 this fluid could mix with the water initially present in the Baliros sands Formation exploited at 684 Nogaro 2. During the second modelled cycle, the added Fluid 3 had a slightly higher $\delta^{11} B$ value 685 at $+12 \%$. Literature data show that the $\delta^{11} \mathrm{~B}$ value of evaporites ranges between +15 up to +35 $686 \%$ according to the evaporation level of the brines (Swihart et al., 1986; Vengosh et al., 1992; 687 Liu et al., 2000). Figure 10 confirms the potential evaporitic origin of this boron. This value is 688 also close to the mixing line between clays and evaporites calculated by Negrel et al. (2009). 689 Therefore we assumed that during this second cycle the boron dissolved in Fluid 3 comes from 690 the molassic aquitard, where evaporitic sediments have been identified. Our study seems to 691 confirm that the top of the productive part of the aquifer and potentially the molasse could be 692 two sources of elements that could feed the exploited part of the aquifer (Baliros sands 693 Formation) according to pressure conditions in the reservoir. 


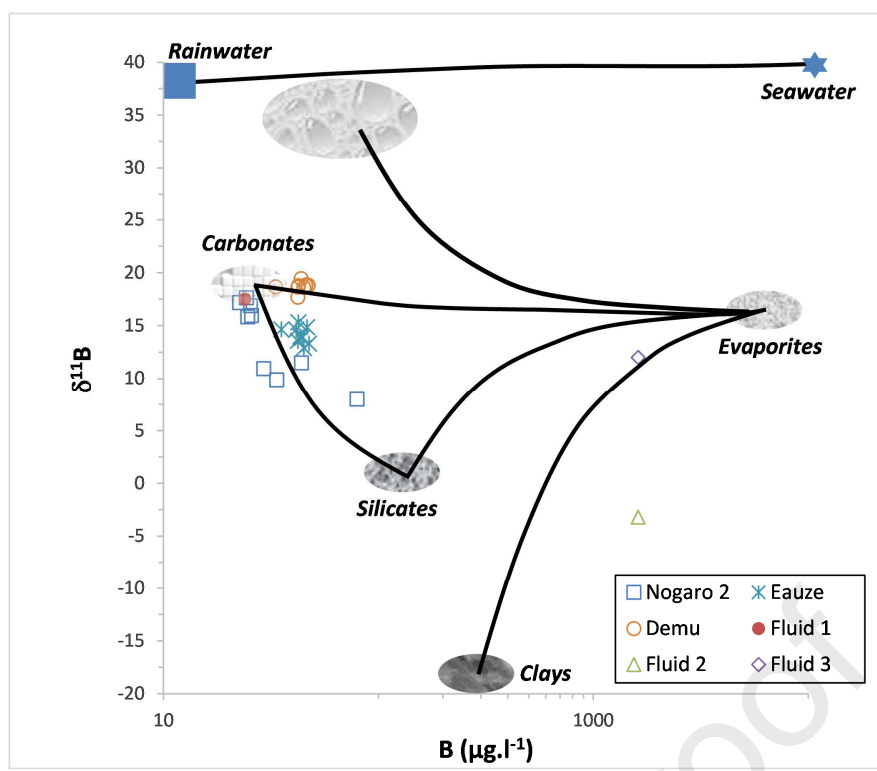

695 Figure 10 - Variations of $\delta^{11} \mathrm{~B}$ versus the boron concentrations in the waters from Nogaro 2, 696 Eauze and Demu. Fluids 1, 2 and 3 correspond to the fluids used for the geochemical 697 calculations. End-members (carbonate, evaporite, clays and silicates) and mixing lines are 698 issued from Négrel et al. (2009).

These potential contributions from the overlying molassic horizons had already been assumed by André (2002). Indeed, the upper formation contains gypsum, identified in cuttings. The upper aquitard would therefore be a sulfate reserve and sulphur could be transferred into the reservoir. We did not investigate the exact transfer mechanisms responsible for the variations of certain elements without impacting the concentration of the other elements in detail. Convection and/or diffusion are potential processes to explain the seasonal fluctuations (Atteia et al., 2005). A sensitive hydrogeologic analysis coupled with the chemical hypothesis defined in this study could help to better characterize them. We can however observe from these chemical simulations that the mixing proportions differ between the dilution and the concentration phases. During the dilution phase, the amounts added every day are relatively high, whereas during the concentration phase the daily amounts are very low. Interpreting this difference is tricky since only the mixing processes are used in this study without any hydraulic constraints. However, one interpretation could be that two processes are in competition. On one side, we can suppose

713 that the dilution phase could be assimilated to a hydraulic process with a high renewal rate of 714 the aquifer water (or a low resident time). On the other side, the concentration phase could correspond to a process with a longer resident time favouring the mixing of the aquifer water with a concentrated solution. Though this study helps us to understanding of the chemical 
717 variations, it also underlines that the aquifer should not be considered as a single horizon and 718 that local structural and hydrogeological heterogeneities may explain vertical differentiation in 719 the aquifer.

720 This does raise a question regarding these geochemical simulations. Since it is assumed that 721 the mixed concentrated fluids are enriched in sulfate and in equilibrium with gypsum, the 722 calcium concentration in solution should increase (Figure 11). But the sulfate increase does not 723 follow the same trend as that of calcium (and/or magnesium). Figure 16 clearly shows that the 724 measured calcium concentrations are lower than the calculated values. This could mean that 725 calcium (and/or magnesium) is controlled by another mechanism.

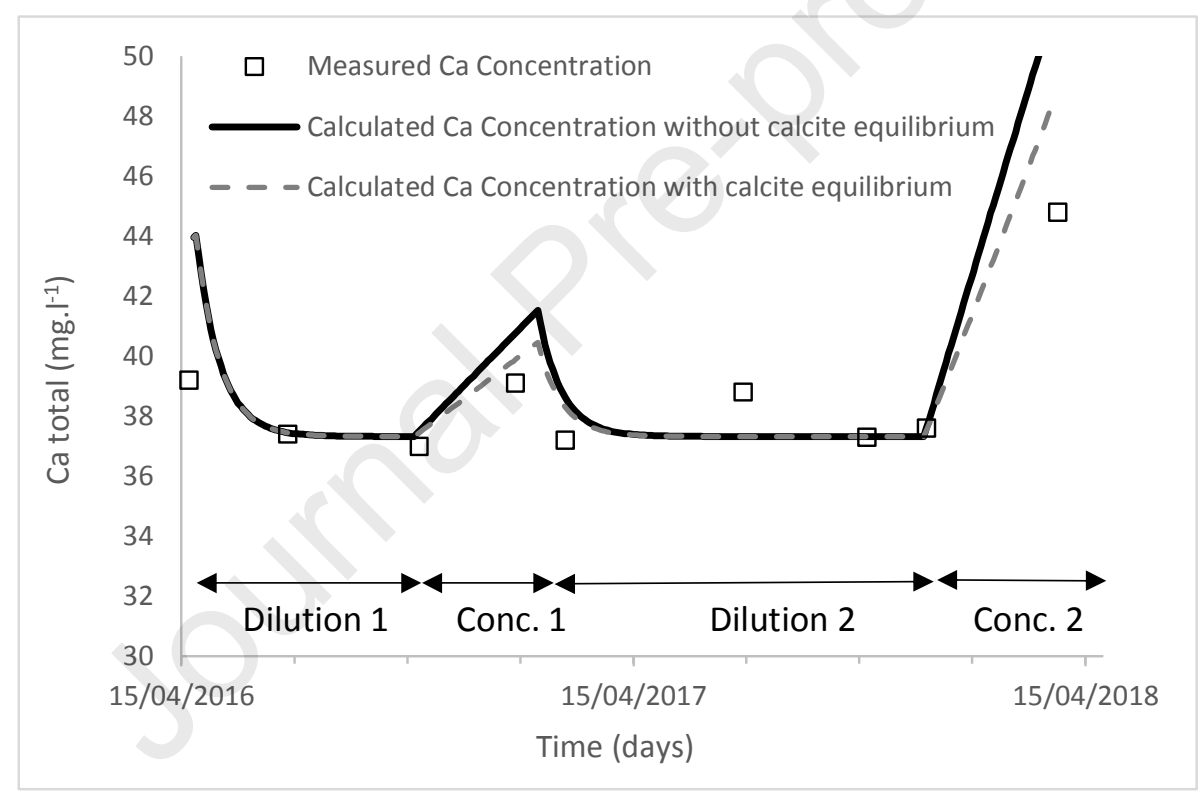

728 Figure 11 - Variation in calcium concentration. Curves are results of two simulations 729 (with and without maintaining calcite equilibrium) whereas symbols are calcium 730 concentration measured during quarterly samplings

731 During the addition of concentrated fluids (Fluids 2 and 3), calcium is added in a solution (Fluid 732 1) initially in equilibrium with calcite. Then the saturation indices of calcite increases and the 733 carbonate mineral becomes over-saturated, whereas the gypsum remains under-saturated 734 (Figure 12). 

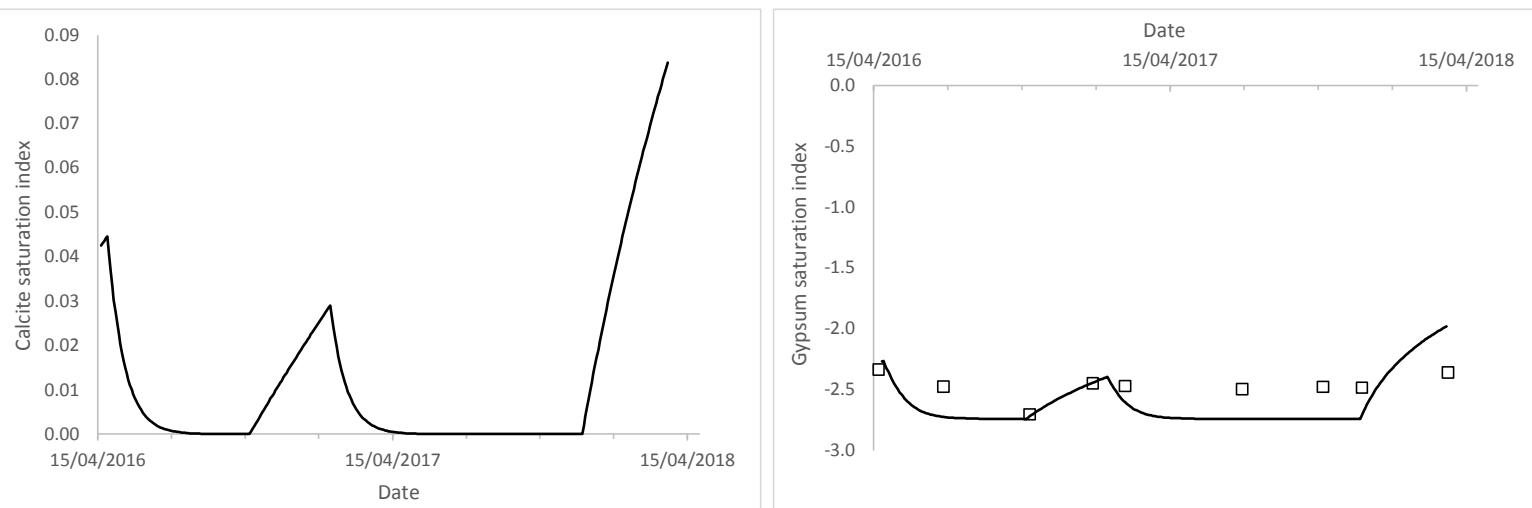

736

Figure 12 - Variation of the simulated saturation indices of calcite (left) and gypsum (right) during the mixing of Fluid 1 with Fluids 2 and 3. Lines are results of simulations whereas symbols are saturation indices calculated from chemical compositions of waters measured during quarterly samplings

Because of calcium's high kinetic reactivity, this mineral is often assumed to be in equilibrium with the solution. A new geochemical run was then performed assuming calcite equilibrium and imposing a $\mathrm{CO}_{2}$ partial pressure of $10^{-2}$ atm during the mixing. Under this condition, the calcium concentration in solution is controlled by calco-carbonic equilibrium and secondary calcite is precipitating in the reservoir. By imposing this constraint to the chemical model, Figure 11 shows that the calcite precipitation controls and decreases the calcium content in the solution and numerical results are more coherent with measured data. Moreover, it is admitted that light isotopes concentrate in the least dense phase, i.e. in the liquid phase instead of the solid phase (Allègre and Michard, 1973 ; Hoefs, 1997; Couchoud, 2008). Consequently, ${ }^{13} \mathrm{C}$ precipitates in priority under calcite, the solution is enriched with the light isotope and the $\delta^{13} \mathrm{C}$ value decreases. It corresponds to the observations in Nogaro 2 since sulfate concentration and $\delta^{13} \mathrm{C}$ are anticorrelated : during the concentration phase, sulfate increases, calcite precipitates and $\delta^{13} \mathrm{C}$ decreases (Figure 6).

\section{6 - Conclusions}

The 2-year monitoring of concentrations of major and trace elements and stable and radioactive isotopes confirms the cyclical and seasonal variations in sulfate (between 10 and $40 \mathrm{mg}^{-1} \mathrm{I}^{-1}$ ) as well as variations in sulfur-34 of sulfate (between +6.5 and $+8.5 \%$ ) at the Nogaro 2 well. Though sulfate variations were known, additional variations in boron (total concentration and isotope) and carbon $\left({ }^{13} \mathrm{C}\right.$ and $\left.{ }^{14} \mathrm{C}\right)$ contents have been also highlighted by these new campaigns. However, given the very small activity in ${ }^{14} \mathrm{C}$, it has been difficult to conclude on the origin of the measured variations (geochemical processes, water mixtures, uncertainties related 
761

762

763

764

765

766

767

768

769

770

771

772

773

774

775

776

777

778

779

780

781

782

783

784

785

786

787

788

789

790

791

792

793

794

to samples and analyses, for instance). Further study of this parameter could be considered, in particular to define the uncertainty associated with abstractions and analyses.

In terms of interpretations, geochemical modelling based on water mixtures has revealed concentration processes in relation with mixtures of sulfate and boron-enriched waters and dilution stages, corresponding to mixes between water from the reservoir and water coming from other origins. While the geochemical models make it possible to properly restore both sulfate and boron concentrations in the water (as well as the $\delta^{34} S$ and $\delta^{11} \mathrm{~B}$ values), this approach must be considered exploratory in order to propose mixing end-members. Ideally, this study should be supplemented by a more accurate analysis of the minerals present at the site (in the reservoir and in the layers both beneath and overlying). This mineral study would allow us to define more precisely the phases bearing sulfur and boron and to characterize them (especially in terms of isotopic content). The geological and mineralogy study we carried out confirms that in the Nogaro 2 zone sulfur may have two origins: gypsum, which is generally present in the molassic aquitard, and pyrite, present in the reservoir. However, it has not been possible to characterize the sulfur of these pyrites precisely, especially in terms of isotope. The small amount of pyrite and the coating of the grains by quartz deposits prevented any purification and isotopic analysis. However, these characterizations would be necessary to determine the origin of sulfate in the waters, especially during peak phases.

This study therefore provides important elements for understanding the processes responsible for variations in sulfate concentration in waters from Nogaro 2. It appears that these variations are probably related to coupled hydrodynamic and geochemical processes and that only a finer characterization of the end-members (origin of sulfur and boron, phases bearing these elements, stock/reserve of these elements, etc.) and exchanges between the different parts of the reservoir (and the aquitards) will help to understand the mechanisms occurring at this borehole. A coupled hydrogeological and chemical approach will also be needed to better understand these processes.

\section{ACKNOWLEDGMENTS}

The authors would like to thank TEREGA, the Adour-Garonne Water Agency and BRGM (the French Geological Survey) for funding this work as part of the GAIA Project. We are grateful to Pierre Chiquet and Pierre Marchet, who helped improve the scientific level of the manuscript thanks to their fruitful comments. The authors warmly thank J. Tremosa for his help in geochemical modelling, E. Decouchon and A. Grandemange for their assistance during field acquisitions and C. Guerrot, A. Montech and C. Flehoc (BRGM's laboratory) for providing isotope analyses. 


\section{REFERENCES}

796

797

798

799

800

801

802

803

804

805

806

807

808

809

810

811

812

813

814

815

816

817

818

819

820

821

822

823

824

825

ADES (2020). https://ades.eaufrance.fr/

AGSO, BRGM (2018). Synthèse géophysique et géologique des Pyrénées - Volumes 2 et 3 : Cycle alpin: Stratigraphie et Phénomènes alpins, Co-édition AGSO et BRGM, 483 p., 286 fig.

Allègre C.J., Michard G. (1973). Introduction à la géochimie. Presses Universitaires de France, $298 p$

André L. (2002) - Contribution of geochemistry to the knowledge of deep underground flows. Application to the Infra-Molassic sands of Aquitain Basin. PhD Thesis. University of Bordeaux 3. 230 p. (in French)

André L., Francheschi M., Pouchan P., Atteia O. (2002) - Origine et évolution du soufre au sein de l'aquifère des Sables infra-molassiques du Bassin aquitain. C.R. Geoscience, 334, 749-756.

André L., Franceschi M., Pouchan P., Atteia O. (2005). Using geochemical data and modelling to enhance the understanding of groundwater flow in a regional deep aquifer, Aquitaine Basin, south-west of France. Journal of Hydrology, 305, 40-62. doi:10.1016/j.jhydrol.2004.08.027

André L., Michelot J.-L., Deschamps P., Decouchon E., Wuilleumier A. (2018). Revision of radiocarbon ages in groundwater from the Eocene aquifer in the Aquitaine basin (France). European Geosciences Union 2018, Vol. 20, EGU2018-7811, Apr. 2018, Vienne, Austria.

Angrand P. (2017). 3D evolution of a retro-foreland basin: the Aquitaine Basin, France. PhD Thesis in Earth Sciences. University of Lorraine. English. tel-01906295.

Atteia O., André L., Dupuy A., Franceschi M. (2005). Contributions of diffusion, dissolution, ion exchange, and leakage from low-permeability layers to confined aquifers. Water Resources Research, American Geophysical Union, 41 (9), 110.1029/2003WR002593).

Barth, S.R. (2000). Geochemical and boron, oxygen and hydrogen isotopic constraints on the origin of salinity in groundwaters from the crystalline basement of the Alpine Foreland. Applied Geochemistry, 15, 937-952.

BEICIP (1984). Modèle géologique de la nappe inframolassique Bassin Aquitain, RueilMalmaison: BEICIP, November 1984, 2 volumes: 46p. + 125 p., 15 pl.

Blavoux B., Dray M., Fehri A., Olive P., Gröning M., Sonntag C., Hauquin J.-P., Pelissier G., Pouchan P. (1993). Paleoclimatic and hydrodynamic approach to the Aquitaine Basin deep aquifer (France) by means of environmental isotopes and noble gases. Int. Symp. App. Isotope Techn. 1993, 293-305. 
826 Bourrouilh R., Richert J.P., Zolnaie, G. (1995). The North Pyrenean Aquitaine Basin, France: 827 Evolution and hydrocarbons. AAPG Bulletin, 79(6), June 1995.

828 Brenot A., Négrel P., Petelet-Giraud E., Millot R., Malcuit E. (2015). Insights from the salinity 829 origins and interconnections of aquifers in a regional scale sedimentary aquifer system (Adour830 Garonne district, SW France): Contributions of $\delta^{34} S$ and $\delta^{18} \mathrm{O}$ from dissolved sulfates and the $831{ }^{87} \mathrm{Sr} /{ }^{86} \mathrm{Sr}$ ratio. Applied Geochemistry, 53, 27-41.

832 Casanova, J., Négrel, Ph., Petelet-Giraud, E., Kloppmann, W. (2002). The evolution of boron 833 isotopic signature of groundwaters through silicate weathering. In $6^{\text {th }}$ International Symposium 834 on the Geochemistry of the Earth's Surface, Hawaii, vol. 6, 7-12.

835 Catanzaro E.J., Champion C.E., Garner E.L., Malinenko G., Sappenfield K.M., Shields K.M. 836 (1970). Boric acid: isotopic and assay standard reference materials. US Nat. Bur. Standards, 837 Spec. Publ. 260-17, 70 pp

838 Cary L., Petelet-Giraud E., Bertrand G., Kloppmann W., Aquilina L., Martins V. et al. (2015). 839 Origins and processes of groundwater salinization in the urban coastal aquifers of Recife 840 (Pernambuco, Brazil): A multi-isotope approach. Science of The Total Environment, 530-531, 841 411-429, https://doi.org/10.1016/j.scitotenv.2015.05.015.

842 Clauer N., Williams L.B., Lemarchand D., Florian P., Honty M. (2018). Illitization decrypted by B 843 and $\mathrm{Li}$ isotope geochemistry of nanometer-sized illite crystals from bentonite beds, East Slovak 844 Basin. Chem. Geol., 477, 177-194. https://doi.org/10.1016/j.chemgeo.2017.10.027

845 Claypool G., Holser W., Kaplan I., Sakai H., Zak I. (1980) - The age curves of sulfur and oxygen 846 isotopes in marine sulfate and their mutual interpretation. Chem. Geol., 28, 199-260.

847 Couchoud I. (2008). Les isotopes stables de l'oxygène et du carbone dans les spéléothèmes 848 des archives paléoenvironnementales. Quaternaire, 19(3), 275-291

849 De Caritat P., Kirstea D., Carrb G., McCulloch M. (2005). Groundwater in the Broken Hill region, 850 Australia: recognising interaction with bedrock and mineralisation using $\mathrm{S}, \mathrm{Sr}$ and $\mathrm{Pb}$ isotopes. 851 Applied Geochemistry, 20, 767-787. https://10.1016/i.apgeochem.2004.11.003

852 Deiana M., Mussi M., Pennisi M. et al. (2020) - Contribution of water geochemistry and isotopes $853\left(\delta^{18} \mathrm{O}, \delta^{2} \mathrm{H},{ }^{3} \mathrm{H},{ }^{87} \mathrm{Sr} /{ }^{86} \mathrm{Sr}\right.$ and $\left.\delta^{11} \mathrm{~B}\right)$ to the study of groundwater flow properties and underlying 854 bedrock structures of a deep landslide. Environ Earth Sci, 79, 30. 855 https://doi.org/10.1007/s12665-019-8772-4 
856

857

858

859

860

861

862

863

864

865

866

867

868

869

870

871

872

873

874

875

876

877

878

879

880

881

882

883

884

885

886

887

Douez O., Dupuy A., Atteia O., Franceschi M. (2006). Assessment of deep aquifer complexity by long period numerical path lines. International FEFLOW User Conference, September 10-15, 2006, Berlin, Germany. 99-106.

Einsiedl F., Pilloni G., Ruth-Anneser B., Lueders T., Griebler C. (2015). Spatial distributions of sulphur species and sulphate-reducing bacteria provide insights into sulphur redox cycling and biodegradation hot-spots in a hydrocarbon-contaminated aquifer. Geochimica et Cosmochimica Acta, 156, 207-221. https://10.1016/i.gca.2015.01.014

Ercolani C., Lemarchand D., Dosseto A. (2019). Insights on catchment-wide weathering regimes from boron isotopes in riverine material. Geochimica et Cosmochimica Acta, 261, 3555, https://doi.org/10.1016/j.gca.2019.07.002.

Gal F., André L., Wuilleumier A. (2018a). Water sampling in low productive boreholes: how to ensure of the representativeness of sampling? Vol. 20, EGU2018-7116, EGU General Assembly 2018, Vienna. Austria. 8-13 April 2018.

Gal F., Barrière J., Bentivegna G., Djemil M., André L., Wuilleumier A. (2018b). New investigations in former hydrocarbon exploration wells in the Aquitaine Basin, France: how to get reliable data? A case study. Vol. 20, EGU2018-7172, EGU General Assembly 2018, Vienna. Austria. 8-13 April 2018

Godfrey L., Álvarez-Amado F. (2020). Volcanic and Saline Lithium Inputs to the Salar de Atacama. Minerals, 10, 201; https://doi:10.3390/min10020201

Gonfiantini R., Tonarini S., Gröning M., Adorni-Braccesi A., Al-Ammar A.S., Astner M., Bächler S., Barnes R.M., Bassett R.L., Cocherie A., Deyhle A., Dini A., Ferrara G., Gaillardet J., Grimm J., Guerrot C., Krähenbühl U., Layne G., Lemarchand D., Meixner A., Northington D.J., Pennisi M., Reitznerová E., Rodushkin I., Sugiura N., Surberg R., Tonn S., Wiedenbeck M., Wunderli S., Xiao Y., Zack T. (2003). Intercomparison of boron isotope and concentration measurements. Part II: evaluation of results. Geostandards Newsletter, 27(1), 41-57.

Harkness J.S., Warner N.R., Ulrich A., Millot R., Kloppmann W., Ahad J.M.E., Savard M.M., Gammon P., Vengosh A. (2018) - Characterization of the boron, lithium, and strontium isotopic variations of oil sands process-affected water in Alberta, Canada. Applied Geochemistry, 90, 50-62, https://doi.org/10.1016/j.apgeochem.2017.12.026.

Hoefs J. (1997). Stable isotopes geochemistry.Springer, Berlin, $241 \mathrm{p}$.

Housse B., Maget Ph. (1977). Potentiel géothermique du Bassin Aquitain, Levallois-Perret : BRGM, Elf Aquitaine (Production), 1977, 167 p., 38 pl. 
889 Infoterre (2020b). http://ficheinfoterre.brgm.fr/InfoterreFiche/ficheBss.action?id=BSS002EGAG

890 Infoterre (2020c). http://ficheinfoterre.brgm.fr/InfoterreFiche/ficheBss.action?id=BSS002EFZJ

891 Johnson J.W., Oelkers E.H., Helgeson H.C. (1992). SUPCRT92: A software package for calculating the standard molal thermodynamic properties of minerals, gases, aqueous species, and reactions from 1 to 5000 bar and 0 to $1000^{\circ} \mathrm{C}$ Computers \& Geosciences, 18(7), 899-947.

894 Labat N. (1998). Rôle de particularités sédimentaires et structurales sur le comportement des 895 sables sous-molassiques soumis aux fluctuations induites par les stockages souterrains de gaz. Application à l'étude de leur influence sur l'hydrodynamisme des émergences locales. PhD 897 Thesis. University of Bordeaux 3, 228 p. (in French).

898 Lemarchand D., Gaillardet J. (2006). Transient features of the erosion of shales in the 899 Mackenzie basin (Canada), evidences from boron isotopes. Earth and Planetary Science Letters, 245, 1-2, 174-189, https://doi.org/10.1016/j.epsl.2006.01.056.

901 Li X., Zhou A., Gan Y., Yu T., Wang D., Liu Y. (2011). Controls on the $\delta^{34} S$ and $\delta^{18} O$ of 902 dissolved sulfate in the Quaternary aquifers of the North China Plain. Journal of Hydrology, $\mathbf{4 0 0}$ 903 (3-4), 312-322. https://doi.org/10.1016/j.jhydrol.2011.01.034

904 Liu, W.G., Xiao, Y.K., Peng, Z.C., An, Z.S., He, X.X. (2000). Boron concentration and isotopic 905 composition of halite from experiments and salt lakes in the Qaidam Basin. Geochimica et 906 Cosmochimica Acta 64, 2177-2183.

907

908

909

910

911

912

913

914

915

Malcuit E. (2012). Origine de la minéralisation des eaux dans un aquifère multicouche profond. Exemple de la "zone minéralisée de l'Entre-Deux-Mers" (Bassin aquitain, France). PhD Thesis. University of Bordeaux 3. 456 p. (in French).

Malcuit E., Atteia O., Larroque F., Franceschi M., Pryet A. (2014). On the role of lowpermeability beds in the acquisition of $\mathrm{F}$ and $\mathrm{SO}_{4}$ concentrations in a multi-layer aquifer, SouthWest France. Journal of Contaminant Hydrology, 169, 37-49MeteoFrance (2020) - Fiche climatologique de Mont-de-Marsan (40). Edition du 06/09/2020.

Millot, R., Négrel, Ph., Petelet-Giraud, E. (2007). Multi-isotopic (Li, B, Sr, Nd) approach for geothermal reservoir characterization in the Limagne Basin (Massif Central, France). Applied Geochemistry, 22, 2307-2325.

Négrel, Ph., Petelet-Giraud, E., Casanova, J., Kloppmann, W. (2002). Boron isotope signatures in the coastal groundwaters of French Guiana, Water Resources Research, 38, https://10.1029/2002WR001299 
920 Négrel, Ph, Petelet-Giraud, E., Brenot, A., Millot, R., Roy, S., Dutartre, Ph, Fournier, I. (2007).

921 Multi isotopic and geochemical constraints of interconnection and heterogeneities of water 922 bodies in the Adour-Garonne district (SW France)-The CARIS-MEAU research project. 923 International Symposium on Advances in Isotope Hydrology and its Role in Sustainable Water 924 Resources Management (IHS-2007);21-25 May 2007 Vienna, Austria. IAEA-CN-151

925 Négrel P., Petelet-Giraud E., Brenot A. (2009). Use of isotopes for groundwater characterization 926 and monitoring. In P. Quevauviller, A.M. Fouillac, J. Grath, \& R. Ward (Eds.), Groundwater 927 monitoring, (pp. 331-354). The Atrium, Southern Gate, Chichester, West Sussex, UK: John 928 Wiley and Sons, Ltd. https://doi.org/10.1002/9780470749685.

929 Négrel P., Millot R., Guerrot C., Petelet-Giraud E., Brenot A., Malcuit E. (2012) - Heterogeneities 930 and interconnections in groundwaters: Coupled B, Li and stable-isotope variations in a large 931 aquifer system (Eocene Sand aquifer, Southwestern France). Chemical Geology, 296-297, 83932 95, https://doi.org/10.1016/j.chemgeo.2011.12.022.

933 Ortega C., Lasseur E., Guillocheau F., Serrano O. (2017). Evolution of sedimentary architecture 934 in retro-foreland basin: Aquitaine basin example from Paleocene to lower Eocene. European 935 Geosciences Union General Assembly 2017, Apr 2017, Wien, Austria

936 Orthiz A. (2019). Géométries et bilan érosion-sédimentation d'un rétro-bassin d'avant pays 937 durant son évolution finie-orogénique et post-orogénique: le cas du système Pyrénées / bassin 938 d'Aquitaine / golfe de Gascogne de 38 à 0 Ma. PhD Thesis, University Rennes 1 (in French).

939 Palmer, M.R., Spivack, A., Edmond, J.M. (1987). Temperature and pH controls over isotopic 940 fractionation during adsorption of boron on marine clay. Geochim. Cosmochim. Acta, 51, 23199412323.

942 Parkhurst D.L., Appelo, C.A.J. (2013) - Description of input and examples for PHREEQC 943 version 3 - A computer program for speciation, batch-reaction, one-dimensional transport, and 944 inverse geochemical calculations: U.S. Geological Survey Techniques and Methods, book 6, 945 chap. A43, $497 \mathrm{p}$.

946 Pearson F.J., Hanshaw B.B. (1970) - Sources of dissolved carbonate species in groundwater 947 and their effects on carbon-14 dating In Isotope Hydrology 1970, IAEA Symposium 129, Mars 948 1970, Vienne, pp. 271-286.

949 Pennisi, M., Leeman, W.P., Tonarini, S., Pennisi, A., Nabelek, P. (2000). Boron, Sr, O, and H 950 isotope geochemistry of groundwaters from Mt. Etna (Sicily) - hydrologic implications. 951 Geochimica et Cosmochimica Acta, 64, 961-974. 
952 Pin C., Bassin C. (1992). Evaluation of a strontium specific extraction chromatographic method 953 for isotopic analysis in geological materials. Analytica Chimica Acta 269, 249-255.

954 Seguin J.J. (2003). Outil de gestion des aquifères du Sud du Bassin Adour-Garonne - Année 4. 955 Calage du modèle hydrodynamique en régime transitoire - BRGM/RP-52041-FR, 80 p.

956 Serrano O. (2001). Le Crétacé Supérieur - Paléogène du Bassin Compressif Nord-Pyrénéen 957 (Bassin de l'Adour). Sédimentologie, Stratigraphie, Géodynamique. PhD Thesis: University of 958 Rennes 1, $252 \mathrm{p}$ (in French).

959 Swihart, G.H., Moore, P.B., Callis, E.L. (1986). Boron isotopic composition of marine and 960 nonmarine evaporite borates. Geochimica et Cosmochimica Acta 50, 1297-1301.

961 Vengosh, A. Starisnky, A., Kolodny, Y., Chivas, A.R., Raab, M. (1992). Boron isotope variations 962 during fractional evaporation of sea water: New constraints on the marine vs. non marine 963 debate. Geology 20, 799-802.

964 TEREGA (2020). https://www2.terega.fr/en/our-projects/storage-projects/tigf-storage.html

965 Wuilleumier A., Douez O. Pedron N., André L., Serrano O., Lasseur E., Saplairoles M. (2018) 966 From recharge to outflows: understanding deep aquifers groundwater circulations. The south 967 Aquitaine Basin case study. Vol. 20, EGU2018-7537, EGU General Assembly 2018, Vienna. 968 Austria. 8-13 April 2018. 


\section{Appendix}

Table A-1: Physico-chemical parameters of the waters measured on site

\begin{tabular}{|c|c|c|c|c|c|c|c|c|}
\hline Well & Date & $\begin{array}{c}\text { Conductivity } \\
(\mu \mathrm{S} / \mathrm{cm})\end{array}$ & pH & $\mathbf{T}^{\circ} \mathbf{C}$ & $\mathrm{O}_{2}(\%)$ & $\mathrm{O}_{2}(\mathrm{mg} / \mathrm{l})$ & $\begin{array}{c}\text { Eh measured } \\
(\mathrm{mV})\end{array}$ & $\begin{array}{c}\text { Eh }_{\text {corrected }} / \text { ENH } \\
(\mathrm{mV})\end{array}$ \\
\hline \multirow{9}{*}{ 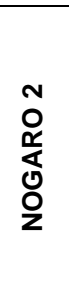 } & 19/04/2016 & 325 & 7.2 & 51 & 42 & 2.35 & -209 & -19 \\
\hline & $18 / 07 / 2016$ & 296 & 7.13 & 50.9 & 3.3 & 0.19 & -284 & -94 \\
\hline & 04/10/2016 & \multicolumn{7}{|c|}{ Not measured } \\
\hline & 10/01/2017 & 347 & 7.17 & 48.7 & & 0.65 & -199 & -7 \\
\hline & 21/03/2017 & 384 & 7.75 & 42.0 & 72.8 & 4.84 & -129 & 68 \\
\hline & 27/06/2017 & 328 & 7.55 & 49.1 & 20.2 & 1.18 & -93 & 98 \\
\hline & 03/10/2017 & 296 & 7.48 & 47.2 & 39.7 & 2.29 & -112 & 81 \\
\hline & 14/12/2017 & 338 & 7.71 & 46 & 67.8 & 4.04 & -122 & 72 \\
\hline & 01/03/2018 & 365 & 7.85 & 44.5 & 82.5 & 4.77 & 94 & 289 \\
\hline \multirow{9}{*}{$\underset{\amalg}{\stackrel{\Perp}{پ}}$} & 19/04/2016 & 308 & 7.32 & 36.4 & 3.2 & 0.21 & $\begin{array}{l}-169 \\
\end{array}$ & 30 \\
\hline & 18/07/2016 & 307 & 7.14 & 36.4 & 5.9 & 0.4 & -215 & -14 \\
\hline & 04/10/2016 & \multicolumn{7}{|c|}{ Not measured } \\
\hline & 10/01/2017 & 333 & 7.4 & 31.5 & & 0.53 & -165 & 39 \\
\hline & $21 / 03 / 2017$ & 325 & 7.73 & 31.8 & 48.2 & 3.76 & -80 & 124 \\
\hline & 27/06/2017 & 330 & 7.75 & 35.5 & 58.8 & 4.01 & 53 & 254 \\
\hline & 03/10/2017 & 319 & 7.23 & 27.8 & 53.9 & 4.2 & 135 & 342 \\
\hline & 14/12/2017 & 326 & 7.65 & 32.0 & 38.5 & 2.78 & 18.4 & 222 \\
\hline & 01/03/2018 & 316 & 7.5 & 34.9 & 40.5 & 2.71 & 95 & 297 \\
\hline \multirow{9}{*}{$\sum_{\text {㟧 }}^{\supset}$} & 19/04/2016 & 298 & 7.38 & 48.1 & 29.1 & 1.83 & -187 & 5 \\
\hline & 18/07/2016 & 293 & 7.14 & 53.9 & 56.8 & 3.10 & -219 & -31 \\
\hline & 04/10/2016 & \multicolumn{7}{|c|}{ Not measured } \\
\hline & 10/01/2017 & 326 & 7.25 & 53.2 & & 0.10 & -198 & -10 \\
\hline & 21/03/2017 & 323 & 7.44 & 46.6 & 14.3 & 0.91 & -145 & 48 \\
\hline & 27/06/2017 & 325 & 7.46 & 48.0 & 15.8 & 0.88 & -125 & 67 \\
\hline & 03/10/2017 & 296 & 7.21 & 53.0 & 3.0 & 0.16 & -211 & -22 \\
\hline & 14/12/2017 & 326 & 7.45 & 49.0 & 15.0 & 0.92 & -173 & 18 \\
\hline & 01/03/2018 & 462 & 7.25 & 48.0 & 12.8 & 0.73 & 52 & 244 \\
\hline
\end{tabular}


Table A-2: Chemical composition of major elements (Concentrations in $\mathrm{mg}^{-1} \mathrm{I}^{\text {) }}$ and calculated molar ratio

\begin{tabular}{|c|c|c|c|c|c|c|c|c|c|c|c|c|}
\hline Date & Well & $\mathrm{Ca}$ & Mg & $\mathbf{K}$ & $\mathrm{Na}$ & $\mathrm{SO}_{4}$ & $\mathrm{HCO}_{3}$ & $\mathrm{Cl}$ & $\mathrm{SiO}_{2}$ & $\frac{\mathrm{Ca}+\mathrm{Mg}}{\mathrm{SO}_{4}}$ & $\frac{C a+M g}{C l}$ & $\frac{N a+K}{C l}$ \\
\hline \multirow{3}{*}{$\begin{array}{l}\frac{0}{1} \\
\frac{1}{\alpha}\end{array}$} & NOGARO 2 & 39.2 & 5.2 & 5.2 & 14.5 & 24.2 & 155 & 7.5 & 23.1 & 4.74 & 11.30 & 3.61 \\
\hline & EAUZE & 35.4 & 5.1 & 5.7 & 15.7 & 19.5 & 153 & 6.5 & 17.4 & 5.39 & 11.96 & 4.52 \\
\hline & DEMU & 32.2 & 4.5 & 5.8 & 17.5 & 6.8 & 160 & 7.9 & 24.5 & 13.98 & 8.90 & 4.09 \\
\hline \multirow{3}{*}{$\frac{0}{\frac{1}{3}}$} & NOGARO 2 & 37.4 & 4.5 & 5.3 & 14.1 & 10.1 & 153 & 7.6 & 24.3 & 10.65 & 10.46 & 3.50 \\
\hline & EAUZE & 36.0 & 5.3 & 5.8 & 16.4 & 18.8 & 150 & 6.5 & 18.9 & 5.71 & 12.21 & 4.70 \\
\hline & DEMU & 33.7 & 4.6 & 5.9 & 18.2 & 7.0 & 157 & 7.9 & 26.3 & 14.15 & 9.27 & 4.23 \\
\hline \multirow{3}{*}{ 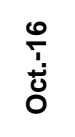 } & NOGARO 2 & 37 & 4.6 & 5.7 & 14.6 & 10.5 & 153 & 7.7 & 24.3 & 10.19 & 10.27 & 3.60 \\
\hline & EAUZE & 36.8 & 5.6 & 6.2 & 17.0 & 23.9 & 149 & 6.6 & 18.9 & 4.62 & 12.38 & 4.83 \\
\hline & DEMU & 32.7 & 4.6 & 6.3 & 18.9 & 6.3 & 158 & 8.0 & 25.7 & 15.34 & 8.94 & 4.36 \\
\hline \multirow{3}{*}{ مَ } & NOGARO 2 & 39.1 & 4.9 & 5.5 & 15.2 & 17.9 & 152 & 7.8 & 24.1 & 6.32 & 10.73 & 3.65 \\
\hline & EAUZE & 35.8 & 5.4 & 6.0 & 16.6 & 19.8 & 148 & 6.7 & 18.4 & 5.42 & 11.84 & 4.64 \\
\hline & DEMU & 33.2 & 4.6 & 6.0 & 19.0 & 6.8 & 155 & 8.1 & 25.8 & 14.39 & 8.93 & 4.29 \\
\hline \multirow{3}{*}{$\begin{array}{l}\bar{T} \\
\frac{1}{\pi} \\
\Sigma\end{array}$} & NOGARO 2 & 37.2 & 4.7 & 5.6 & 14.9 & 14.9 & 154 & 7.5 & 24.6 & 7.24 & 10.64 & 3.74 \\
\hline & EAUZE & 35.3 & 5.3 & 5.9 & 16.6 & 19.8 & 151 & 6.3 & 18.8 & 5.34 & 12.40 & 4.92 \\
\hline & DEMU & 33.1 & 4.7 & 6.0 & 18.6 & 6.4 & 159 & 7.8 & 26.5 & 15.31 & 9.29 & 4.38 \\
\hline \multirow{3}{*}{$\stackrel{\nwarrow}{\frac{1}{5}}$} & NOGARO 2 & 38.8 & 4.4 & 5.5 & 14.5 & 10.7 & 149 & 7.6 & 25.4 & 10.33 & 10.75 & 3.60 \\
\hline & EAUZE & 37.3 & 5.1 & 6.0 & 16.7 & 19.7 & 145 & 6.5 & 19.5 & 5.57 & 12.48 & 4.80 \\
\hline & DEMU & 34.5 & 4.4 & 6.2 & 18.7 & 6.9 & 152 & 7.9 & 26.8 & 14.52 & 9.38 & 4.37 \\
\hline \multirow{3}{*}{ 돔 } & NOGARO 2 & 37.3 & 4.5 & 5.2 & 13.5 & 10.6 & 154 & 7.7 & 23.1 & 10.12 & 10.31 & 3.32 \\
\hline & EAUZE & 36.6 & 5.3 & 5.8 & 15.6 & 20.2 & 151 & 6.7 & 17.3 & 5.39 & 12.01 & 4.38 \\
\hline & DEMU & 33.4 & 4.6 & 5.9 & 17.5 & 6.6 & 158 & 8.1 & 24.5 & 14.90 & 8.98 & 4.00 \\
\hline \multirow{3}{*}{ 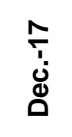 } & NOGARO 2 & 37.6 & 4.5 & 5.6 & 14.1 & 11.2 & 153 & 7.7 & 24.3 & 9.64 & 10.38 & 3.49 \\
\hline & EAUZE & 37.1 & 5.3 & 6.0 & 16.4 & 23.2 & 149 & 6.5 & 19.1 & 4.74 & 12.51 & 4.73 \\
\hline & DEMU & 33.2 & 4.6 & 6.1 & 18.0 & 6.4 & 157 & 8.0 & 26.3 & 15.29 & 9.05 & 4.17 \\
\hline \multirow{3}{*}{$\frac{\infty}{\frac{1}{\pi}}$} & NOGARO 2 & 44.8 & 6.3 & 5.7 & 16.3 & 46.7 & 154 & 7.6 & 24.9 & 2.84 & 12.89 & 3.99 \\
\hline & EAUZE & 35.4 & 5.3 & 5.9 & 15.9 & 20.4 & 151 & 6.7 & 19.0 & 5.19 & 11.69 & 4.46 \\
\hline & DEMU & 32.8 & 4.5 & 6.0 & 17.8 & 7.1 & 158 & 8.1 & 26.5 & 13.59 & 8.81 & 4.06 \\
\hline
\end{tabular}


Table A-3: Concentrations of trace elements

\begin{tabular}{|c|c|c|c|c|c|c|c|c|c|c|}
\hline Date & Well & $\begin{array}{c}\mathrm{Al} \\
\mu \mathrm{g} / \mathrm{l}\end{array}$ & $\begin{array}{c}\text { B } \\
\mu \mathrm{g} / \mathrm{l}\end{array}$ & $\begin{array}{c}\mathrm{Ba} \\
\mu \mathrm{g} / \mathrm{l}\end{array}$ & $\begin{array}{c}\mathrm{F} \\
\mathrm{mg} / \mathrm{l}\end{array}$ & $\begin{array}{c}\mathrm{Fe} \\
\mathrm{mg} / \mathrm{l}\end{array}$ & $\begin{array}{c}\mathrm{Li} \\
\mu \mathrm{g} / \mathrm{l}\end{array}$ & $\begin{array}{c}\mathrm{Mn} \\
\mu \mathrm{g} / \mathrm{l}\end{array}$ & $\begin{array}{c}\mathrm{Sr} \\
\mu \mathrm{g} / \mathrm{l}\end{array}$ & $\begin{array}{c}\mathrm{Br} \\
\mu \mathrm{g} / \mathrm{l}\end{array}$ \\
\hline \multirow{3}{*}{$\begin{array}{l}0 \\
\frac{1}{4} \\
\frac{1}{\alpha}\end{array}$} & NOGARO 2 & 1.13 & 43.9 & 120 & 0.2 & 0.208 & 11.20 & 7.8 & 496 & $<L Q$ \\
\hline & EAUZE & 0.66 & 42.2 & 95 & 0.2 & 0.108 & 10.20 & 12.3 & 466 & 81 \\
\hline & DEMU & 1.61 & 42.3 & 113 & 0.2 & 0.232 & 13.80 & 13.4 & 457 & 54 \\
\hline \multirow{3}{*}{$\frac{0}{\frac{1}{3}}$} & NOGARO 2 & 1.02 & 24.3 & 111 & 0.2 & 0.225 & 9.38 & 6.4 & 438 & $<50$ \\
\hline & EAUZE & 0.58 & 42.5 & 97 & 0.2 & 0.104 & 10.20 & 11.9 & 475 & $<50$ \\
\hline & DEMU & 1.40 & 43.7 & 112 & 0.2 & 0.210 & 13.90 & 12.1 & 468 & $<50$ \\
\hline \multirow{3}{*}{$\frac{0}{\stackrel{+}{0}}$} & NOGARO 2 & 1.92 & 24.7 & 104 & 0.2 & 0.184 & 9.88 & 5.2 & 455 & 145 \\
\hline & EAUZE & 1.16 & 47.6 & 90 & 0.2 & 0.109 & 11.60 & 12.6 & 480 & 208 \\
\hline & DEMU & 1.05 & 47.2 & 105 & 0.2 & 0.265 & 15.20 & 19.4 & 457 & 99 \\
\hline \multirow{3}{*}{ 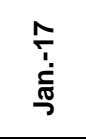 } & NOGARO 2 & 0.6 & 29.3 & 91.4 & 0.2 & 0.309 & 8.27 & 10.9 & 436 & $<L Q$ \\
\hline & EAUZE & 0.56 & 35.4 & 80.5 & 0.2 & 0.349 & 8.97 & 13.9 & 445 & $<\mathrm{LQ}$ \\
\hline & DEMU & 0.73 & 33.3 & 93.1 & 0.2 & 0.343 & 10.9 & 12.7 & 434 & $<\mathrm{LQ}$ \\
\hline \multirow{3}{*}{$\frac{\sim}{\frac{1}{\pi}}$} & NOGARO 2 & NM & 33.7 & 109 & 0.2 & 0.192 & 11.2 & 6.63 & 442 & 157 \\
\hline & EAUZE & NM & 45.1 & 91.7 & 0.2 & 0.191 & 11.2 & 17.1 & 458 & 147 \\
\hline & DEMU & NM & 46.1 & 109 & 0.2 & 0.122 & 15.3 & 18.6 & 440 & 129 \\
\hline \multirow{3}{*}{$\frac{\mathfrak{5}}{5}$} & NOGARO 2 & 1.52 & 25.4 & 110.00 & 0.1 & $<L Q$ & 9.86 & 6.4 & 433 & 29.0 \\
\hline & EAUZE & 1.90 & 46.6 & 111.00 & 0.2 & 0.173 & 14.5 & 12.6 & 473 & 34.6 \\
\hline & DEMU & 0.61 & 46.0 & 95.60 & 0.2 & $<\mathrm{LQ}$ & 10.5 & 12.4 & 470 & 27.1 \\
\hline \multirow{3}{*}{$\frac{N}{\frac{1}{0}}$} & NOGARO 2 & 1.52 & 22.6 & 112.00 & 0.1 & 0.2 & 10.1 & 5.52 & 414 & 67.1 \\
\hline & EAUZE & 1.47 & 41.5 & 96.20 & 0.2 & $<0.02$ & 10.7 & 12.6 & 462 & 44.7 \\
\hline & DEMU & 1.46 & 42.3 & 113.00 & 0.2 & 0.376 & 14.4 & 17.2 & 450 & 49.0 \\
\hline \multirow{3}{*}{ مَّ } & NOGARO 2 & 1.90 & 25.7 & 105.00 & 0.1 & 0.05 & 10.4 & 5.51 & 309 & 28.6 \\
\hline & EAUZE & 0.90 & 43.4 & 86.60 & 0.2 & $<0.02$ & 10.5 & 11.5 & 330 & 24.8 \\
\hline & DEMU & 1.43 & 42.5 & 106.00 & 0.2 & 0.352 & 14.0 & 15.0 & 319 & 34.0 \\
\hline \multirow{3}{*}{$\frac{\infty}{\frac{1}{\pi}}$} & NOGARO 2 & 1.95 & 79.5 & 101.87 & 0.2 & 0.027 & 14.71 & 8.83 & 570 & 30.9 \\
\hline & EAUZE & 0.69 & 44.3 & 93.93 & 0.2 & 0.036 & 9.51 & 12.13 & 455 & 28.4 \\
\hline & DEMU & 2.00 & 45.1 & 109.36 & 0.2 & 0.214 & 14.68 & 11.84 & 449 & 36.4 \\
\hline
\end{tabular}


Table A-4: ${ }^{2} \mathrm{H}$ and $\delta^{18} \mathrm{O}$ of water molecule

\begin{tabular}{|c|c|c|c|c|c|c|c|c|}
\hline & \multicolumn{4}{|c|}{$\delta \mathrm{D}(\% \circ$ vs SMOW) (+/- $0.8 \%$ ) } & \multicolumn{4}{|c|}{$\delta^{18} \mathrm{O}(\% \circ$ vs SMOW) (+/- $0.1 \%$ ) } \\
\hline & Apr-16 & Jul-16 & Oct-16 & Jan-17 & Apr-16 & Jul-16 & Oct-16 & Jan-17 \\
\hline NOGARO 2 & -54.3 & -54.7 & -54.3 & -54.5 & -8.5 & -8.5 & -8.5 & -8.5 \\
\hline EAUZE & -52.6 & -52.5 & -52.7 & -53.0 & -8.3 & -8.3 & -8.2 & -8.4 \\
\hline DEMU & -52.7 & -52.7 & -52.6 & -53.0 & -8.3 & -8.3 & -8.4 & -8.3 \\
\hline
\end{tabular}

Table A-5: ${ }^{87} \mathrm{Sr}{ }^{\beta 6} \mathrm{Sr}$ ratio

\begin{tabular}{c|cc|cc|cc|cc} 
& \multicolumn{2}{|c|}{ Apr-16 } & \multicolumn{2}{c|}{ Jul-16 } & \multicolumn{2}{c|}{ Oct-16 } & \multicolumn{2}{c}{ Jan-17 } \\
\hline & ${ }^{87} \mathbf{S r} /{ }^{86} \mathbf{S r}$ & $\mathbf{2 \sigma}(\mathbf{m})$ & ${ }^{87} \mathbf{S r} /{ }^{86} \mathbf{S r}$ & $\mathbf{2 \sigma}(\mathbf{m})$ & ${ }^{87} \mathbf{S r} /{ }^{86} \mathbf{S r}$ & $\mathbf{2 \sigma}(\mathbf{m})$ & ${ }^{87} \mathbf{S r} /{ }^{86} \mathbf{S r}$ & $\mathbf{2 \sigma}(\mathbf{m})$ \\
\hline NOGARO 2 & 0.708704 & 0.000008 & 0.708712 & 0.000007 & 0.708717 & 0.000007 & 0.708710 & 0.000006 \\
EAUZE & 0.708698 & 0.000005 & 0.708700 & 0.000006 & 0.708701 & 0.000008 & 0.708700 & 0.000008 \\
DEMU & 0.708781 & 0.000006 & 0.708778 & 0.000009 & 0.708778 & 0.000006 & 0.708774 & 0.000008
\end{tabular}

Table A-6: Isotope concentrations

\begin{tabular}{|c|c|c|c|c|c|c|c|c|c|}
\hline Date & Well & $\begin{array}{c}\delta^{13} \mathrm{C} \\
\% \circ \text { vs PDB } \\
( \pm 0.1)\end{array}$ & $\begin{array}{c}\text { Act. }{ }^{14} \mathrm{C} \\
\text { (pMC) }\end{array}$ & $\begin{array}{c}\delta^{11} \mathbf{B} \\
\% \circ(\operatorname{Try} 1)\end{array}$ & $\underset{\%}{ \pm \underset{\%}{2 \sigma}(\mathrm{m})}$ & $\begin{array}{c}\delta^{11} \mathbf{B} \\
\% \circ(\operatorname{Try} 2)\end{array}$ & $\underset{\%}{ \pm 2 \sigma(m)}$ & $\begin{array}{r}\delta^{34} \mathrm{~S}\left(\mathrm{SO}_{4}\right) \\
\% \circ \text { vs CDT } \\
( \pm 0.3 \% \text { \% }\end{array}$ & $\begin{array}{c}\delta^{18} \mathrm{O}\left(\mathrm{SO}_{4}\right) \\
\% ॰ \text { vs SMOW } \\
( \pm 0.5 \% \text { ) }\end{array}$ \\
\hline \multirow{3}{*}{$\begin{array}{l}\frac{0}{1} \\
\frac{\bar{\alpha}}{\alpha}\end{array}$} & NOGARO 2 & -14.60 & $1.8 \pm 0.1$ & 11.67 & 0.06 & 11.49 & 0.11 & 8.00 & 13.5 \\
\hline & EAUZE & -14.60 & $1.5 \pm 0.1$ & 13.97 & 0.06 & 13.58 & 0.08 & 9.30 & 12.8 \\
\hline & DEMU & -15.30 & $3.2 \pm 0.1$ & 17.94 & 0.04 & 17.70 & 0.09 & 15.90 & 10.2 \\
\hline \multirow{3}{*}{$\frac{0}{\frac{1}{3}}$} & NOGARO 2 & -14.80 & $1.5 \pm 0.1$ & 17.57 & 0.07 & 17.63 & 0.09 & 6.80 & $10.6( \pm 0.6 \%$ o $)$ \\
\hline & EAUZE & -14.30 & $0.5 \pm 0.1$ & 15.23 & 0.09 & 15.32 & 0.06 & 9.50 & $14.1( \pm 0.6 \%$ o $)$ \\
\hline & DEMU & -15.50 & $1.1 \pm 0.1$ & 19.47 & 0.06 & 19.44 & 0.11 & 15.80 & 10.7 \\
\hline \multirow{3}{*}{$\begin{array}{l}0 \\
\frac{1}{4} \\
0\end{array}$} & NOGARO 2 & -14.30 & $2.0 \pm 0.1$ & 15.45 & 0.05 & 15.83 & 0.08 & $6.80( \pm 0.4 \% \circ)$ & 10.4 \\
\hline & EAUZE & -14.00 & $0.1 \pm 0.1$ & 13.68 & 0.06 & 13.31 & 0.08 & 9.50 & 12.3 \\
\hline & DEMU & -15.30 & $1.5 \pm 0.1$ & 19.03 & 0.05 & 18.81 & 0.08 & 18.40 & 11.5 \\
\hline \multirow{3}{*}{ Nָ } & NOGARO 2 & -15.00 & $1.3 \pm 0.0$ & 10.95 & 0.09 & 11.23 & 0.05 & 8.10 & 13.0 \\
\hline & EAUZE & -14.80 & $<0.44$ & 14.65 & 0.08 & 14.28 & 0.06 & 10.00 & 13.0 \\
\hline & DEMU & -15.70 & $0.9 \pm 0.0$ & 18.67 & 0.05 & 18.61 & 0.07 & 17.90 & 11.0 \\
\hline \multirow{3}{*}{$\frac{n}{\overline{1}}$} & NOGARO 2 & -15.20 & $1.7 \pm 0.0$ & 9.64 & 0.06 & 9.89 & 0.04 & 7.00 & 11.00 \\
\hline & EAUZE & -15.30 & $0.8 \pm 0.0$ & 12.80 & 0.05 & 12.90 & 0.04 & 10.00 & 12.60 \\
\hline & DEMU & -15.50 & $0.8 \pm 0.0$ & 19.02 & 0.17 & 18.84 & 0.10 & 17.80 & 11.40 \\
\hline \multirow{3}{*}{$\begin{array}{l}\mathfrak{1} \\
\vdots \\
5 \\
3\end{array}$} & NOGARO 2 & -14.60 & $1.9 \pm 0.0$ & 16.90 & 0.18 & 17.09 & 0.14 & 6.50 & 10.50 \\
\hline & EAUZE & -13.70 & $1.4 \pm 0.0$ & 14.86 & 0.27 & 14.66 & 0.09 & 9.60 & 12.60 \\
\hline & DEMU & -15.30 & $1.1 \pm 0.0$ & 18.80 & 0.07 & 18.94 & 0.06 & 17.10 & 11.20 \\
\hline \multirow{3}{*}{$\frac{\hat{I}}{0}$} & NOGARO 2 & -13.00 & $1.5 \pm 0.0$ & 17.16 & 0.03 & 17.17 & 0.05 & 6.60 & 11.10 \\
\hline & EAUZE & -13.80 & $0.9 \pm 0.0$ & 14.63 & 0.03 & 14.25 & 0.05 & 9.80 & 13.30 \\
\hline & DEMU & -14.90 & $0.9 \pm 0.0$ & 18.65 & 0.04 & 18.82 & 0.04 & 20.00 & 11.80 \\
\hline \multirow{3}{*}{ 宽 } & NOGARO 2 & -13.80 & $2.2 \pm 0.0$ & 15.94 & 0.04 & 15.97 & 0.05 & 6.70 & 11.20 \\
\hline & EAUZE & -11.30 & $1.7 \pm 0.0$ & 14.18 & 0.05 & 13.98 & 0.06 & 9.20 & 13.40 \\
\hline & DEMU & -14.50 & $1.1 \pm 0.0$ & 18.91 & 0.10 & 18.77 & 0.18 & 17.80 & 11.40 \\
\hline \multirow{3}{*}{$\begin{array}{l}\infty \\
\frac{1}{1} \\
\frac{\pi}{\Sigma}\end{array}$} & NOGARO 2 & -13.80 & $1.5 \pm 0.0$ & 7.98 & 0.05 & 7.57 & 0.18 & 8.20 & 14.60 \\
\hline & EAUZE & -14.00 & $0.6 \pm 0.0$ & 13.89 & 0.06 & 13.76 & 0.23 & 9.20 & 13.20 \\
\hline & DEMU & -15.10 & $1.0 \pm 0.0$ & 18.62 & 0.05 & 18.17 & 0.04 & 17.90 & 11.50 \\
\hline
\end{tabular}

$<\mathrm{LQ}$ : lower to quantification limits ; NM : not measured 
Table A-7: Saturation indices of minerals calculated with PHREEQC program and

THERMODDEM database (Blanc et al., 2012)

\begin{tabular}{|c|c|c|c|c|c|c|c|c|c|c|c|c|}
\hline Well & Date & 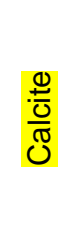 & $\begin{array}{l}\stackrel{0}{=} \\
\text { 응 } \\
\text { 음 }\end{array}$ & 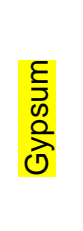 & 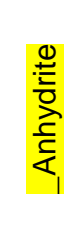 & 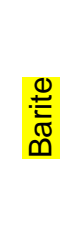 & 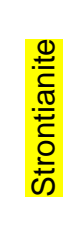 & $\frac{N}{\frac{N}{\sigma}}$ & 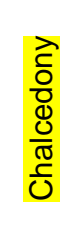 & 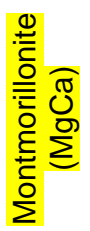 & $\begin{array}{l}\widehat{\widehat{\Delta}} \\
\stackrel{\Phi}{.0} \\
\stackrel{\underline{\equiv}}{=}\end{array}$ & 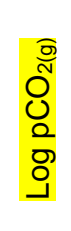 \\
\hline \multirow{9}{*}{ 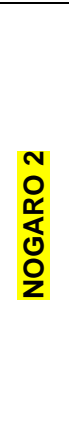 } & $19 / 04 / 2016$ & -0.05 & -0.40 & -2.27 & -2.19 & -0.24 & -1.66 & 0.01 & -0.25 & -0.72 & -0.99 & -1.84 \\
\hline & $18 / 07 / 2016$ & -0.14 & -0.61 & -2.65 & -2.57 & -0.64 & -1.78 & 0.04 & -0.22 & -0.68 & -0.89 & -1.77 \\
\hline & $04 / 10 / 2016$ & -0.28 & -0.90 & -2.64 & -2.57 & -0.64 & -1.90 & 0.05 & -0.21 & -0.09 & 0.26 & -1.65 \\
\hline & $10 / 01 / 2017$ & -0.12 & -0.58 & -2.40 & -2.34 & -0.46 & -1.77 & 0.06 & -0.21 & -0.93 & -1.36 & -1.83 \\
\hline & $21 / 03 / 2017$ & 0.34 & 0.30 & -2.52 & -2.53 & -0.39 & -1.24 & 0.14 & -0.13 & $N C$ & $N C$ & -2.46 \\
\hline & $27 / 06 / 2017$ & 0.25 & 0.13 & -2.62 & -2.56 & -0.61 & -1.40 & 0.07 & -0.19 & -0.44 & -0.90 & -2.22 \\
\hline & 03/10/2017 & 0.16 & -0.05 & -2.64 & -2.60 & -0.58 & -1.49 & 0.05 & -0.21 & -0.42 & -0.68 & -2.15 \\
\hline & $14 / 12 / 2017$ & 0.36 & 0.35 & -2.62 & -2.59 & -0.57 & -1.40 & 0.09 & -0.18 & -0.23 & -0.61 & -2.39 \\
\hline & 01/03/2018 & 0.52 & 0.73 & -1.98 & -1.96 & 0.02 & -1.04 & 0.11 & -0.15 & -0.11 & -0.65 & -2.55 \\
\hline \multirow{9}{*}{ 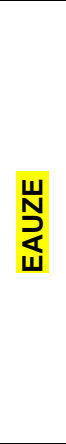 } & $19 / 04 / 2016$ & -0.19 & -0.74 & -2.44 & -2.50 & -0.27 & -1.69 & 0.06 & -0.22 & -0.60 & -0.39 & -2.06 \\
\hline & $18 / 07 / 2016$ & -0.37 & -1.09 & -2.44 & -2.50 & -0.27 & -1.87 & 0.10 & -0.18 & -0.45 & -0.12 & -1.89 \\
\hline & 04/10/2016 & -0.03 & -0.41 & -2.34 & -2.42 & -0.19 & -1.53 & 0.11 & -0.17 & -0.03 & 0.30 & -2.27 \\
\hline & $10 / 01 / 2017$ & -0.19 & -0.77 & -2.43 & -2.54 & -0.27 & -1.69 & 0.14 & -0.14 & -0.27 & 0.01 & -2.19 \\
\hline & $21 / 03 / 2017$ & 0.14 & -0.10 & -2.44 & -2.54 & -0.21 & -1.34 & 0.14 & -0.13 & $N C$ & $N C$ & -2.51 \\
\hline & $27 / 06 / 2017$ & 0.22 & 0.05 & -2.42 & -2.48 & -0.19 & -1.29 & 0.12 & -0.16 & 0.18 & 0.40 & -2.53 \\
\hline & 03/10/2017 & -0.40 & -1.23 & -2.42 & -2.56 & -0.13 & -1.87 & 0.16 & -0.12 & 0.69 & 1.90 & -2.04 \\
\hline & $14 / 12 / 2017$ & 0.08 & -0.25 & -2.36 & -2.46 & -0.18 & -1.57 & 0.15 & -0.13 & -0.05 & 0.11 & -2.44 \\
\hline & 01/03/2018 & -0.04 & -0.44 & -2.42 & -2.49 & -0.23 & -1.54 & 0.11 & -0.16 & -0.39 & -0.34 & -2.26 \\
\hline \multirow{9}{*}{$\sum_{\text {岃 }}^{P}$} & $19 / 04 / 2016$ & 0.03 & -0.24 & -2.89 & -2.83 & -0.77 & -1.51 & 0.07 & -0.19 & -0.29 & -0.41 & -2.02 \\
\hline & 18/07/2016 & -0.12 & -0.50 & -2.83 & -2.73 & -0.82 & -1.70 & 0.04 & -0.22 & -0.53 & -0.72 & -1.75 \\
\hline & 04/10/2016 & -0.08 & -0.41 & -2.89 & -2.80 & -0.88 & -1.66 & 0.04 & -0.22 & -0.76 & -1.09 & -1.81 \\
\hline & $10 / 01 / 2017$ & -0.03 & -0.32 & -2.86 & -2.76 & -0.90 & -1.63 & 0.04 & -0.22 & -1.05 & -1.67 & -1.87 \\
\hline & $21 / 03 / 2017$ & 0.07 & -0.15 & -2.91 & -2.87 & -0.80 & -1.49 & 0.12 & -0.14 & $N C$ & $N C$ & -2.10 \\
\hline & $27 / 06 / 2017$ & 0.11 & -0.11 & -2.85 & -2.80 & -0.84 & -1.45 & 0.11 & -0.15 & -0.88 & -1.60 & -2.13 \\
\hline & 03/10/2017 & -0.06 & -0.39 & -2.87 & -2.77 & -0.83 & -1.65 & 0.02 & -0.24 & -0.60 & -0.79 & -1.82 \\
\hline & $14 / 12 / 2017$ & 0.11 & -0.06 & -2.90 & -2.84 & -0.83 & -1.60 & 0.09 & -0.17 & -0.36 & -0.68 & -2.10 \\
\hline & 01/03/2018 & -0.10 & -0.50 & -2.86 & -2.81 & -0.76 & -1.66 & 0.11 & -0.16 & 0.09 & 0.24 & -1.90 \\
\hline
\end{tabular}




\section{Highlights :}

- Deep confined aquifers can be submitted to heavy and seasonal pressure variations

- Cyclic variations of sulfate and boron are observed over an extended area

- Concentration and isotope ratios of the two elements vary in accordance with each other

- Geochemical modelling based on water mixes fits the field observations

- Observations and simulations confirm water and mass fluxes within deep aquifers 


\section{Declaration of interests}

$\bigotimes$ The authors declare that they have no known competing financial interests or personal relationships that could have appeared to influence the work reported in this paper.

$\square$ The authors declare the following financial interests/personal relationships which may be considered as potential competing interests: 